\title{
Plankton community structure and variability in the Scotia Sea: austral summer 2003
}

\author{
Peter Ward*, Rachael Shreeve, Angus Atkinson, Beki Korb, Mick Whitehouse, \\ Sally Thorpe, David Pond, Nathan Cunningham
}

British Antarctic Survey, Natural Environment Research Council, High Cross, Madingley Rd., Cambridge CB3 0ET, UK

\begin{abstract}
Plankton community structure in the Scotia Sea was investigated during January/early February 2003 based on phytoplankton cell counts from $20 \mathrm{~m}$ depth and mesozooplankton counts from 0 to $400 \mathrm{~m}$ net hauls. Cluster analysis and multi-dimensional scaling revealed 4 major groups of stations within each ordination that broadly corresponded geographically. A grouping of stations to the east of the Antarctic Peninsula was characterised by low phytoplankton cell counts. The corresponding grouping of stations in the mesozooplankton data were characterised by low abundance, overwintered state of many species, low egg production rates, and low carbon mass of copepod instars. In contrast, groupings of stations in the northern part of the Scotia Sea were characterised as chlorophyll and mesozooplankton rich, and the summer generation was well advanced. Latitude was most strongly correlated with mesozooplankton community pattern (rank correlation $\rho=0.608$ ), whereas surface chlorophyll a was a weaker correlate $(\rho=0.344)$ but along with measures of sizefractioned chlorophyll contributed towards explaining variation in species stages carbon mass and egg production rates. Additional hauls to $1000 \mathrm{~m}$ with an LHPR indicated copepod populations were broadly in an overwintered state in the south of the region, whereas to the north of South Georgia recruitment had been completed and some species were undergoing a seasonal descent. A comparison with January/February 2000 revealed higher abundances of krill larvae throughout the Scotia Sea in 2000 as well as a more advanced generation of the copepod Calanoides acutus. Ice cover during the 2 years differed considerably; in 2000 the position of the summer ice edge broadly accorded with the 25 yr average, whereas in 2003 the ice edge lay much further north than usual. We suggest that the timing of ice retreat influenced the timing of reproduction with the late retreat in 2003 causing delayed reproduction and reduced population sizes.
\end{abstract}

KEY WORDS: Southern Ocean · Phytoplankton · Zooplankton · Community structure $\cdot$ Production · Sea ice

Resale or republication not permitted without written consent of the publisher

\section{INTRODUCTION}

Concern over the consequences of climate change makes it increasingly necessary to understand how ocean ecosystem structure and dynamics are related to environmental variability. Trends in long-term data from the Northeast Atlantic and European shelf seas increasingly point to large-scale, climate-mediated changes of plankton populations, albeit with considerable regional variability (Planque \& Taylor 1998, Edwards et al. 2002). In the Southern Ocean extensive time-series data are presently lacking, although recent findings by Atkinson et al. (2004) suggest a dramatic decline in krill abundance has taken place in recent decades, particularly in the Atlantic sector, which may be related to changes in sea-ice distribution. Whilst satellite technologies have dramatically improved our ability to view the Southern Ocean in terms of sea-ice cover, sea-surface temperature, sea-surface height and phytoplankton distribution over large spatial and temporal scales, our present view of zooplankton distribution and dynamics is largely a composite derived from 
shipboard surveys carried out at sub-basin scales in different years and places (e.g. Mackintosh 1934, Marr 1962, Andrews 1966, Atkinson 1991). Nonetheless one characteristic feature of the larger-scale environment that has been clear for some time is that a latitudinal gradient in production cycles exists within the Southern Ocean, with community development commencing earlier in the northern part of the Antarctic Circumpolar Current (ACC) during spring and summer, compared to further south (Hart 1942, Voronina 1970).

Repeated observations at smaller spatial scales have also established variability in the timing and extent of production processes within different regions (e.g. Whitehouse et al. 1996) and within various taxonomic groups (e.g. Brinton et al. 1986, 1987, Siegel \& Loeb 1995, Shreeve et al. 2002). Despite the formidable logistical difficulties in surveying such a large and complex area, a number of surveys undertaken in various parts of the Southern Ocean in the last 20 or so years have provided quasi-synoptic views of community structure. Many of these surveys have used the macroplankton catch composition to provide a view of community structure (e.g. Piatkowski 1989, Hosie 1994, Hosie et al. 2000), whereas others have used the more ubiquitous mesozooplankton provided by finer mesh nets (e.g. Errhif et al. 1997, Pakhomov et al. 2000, Ward et al. 2004). Both approaches provide differing views of community structure, although there is general agreement about many of the factors that structure such communities. Thus the positions of frontal zones such as the Antarctic Polar Front (APF) and the Antarctic Divergence are in many studies consistent with discontinuities in zooplankton distribution (Boysen-Ennen et al. 1991, Longhurst 1998, Hosie et al. 2000, Pakhomov et al. 2000, Ward et al. 2002); zooplankton abundance is often elevated within frontal zones either through physical concentration (Voronina 1970, Franks 1992) or because fronts are productive (Fransz \& Gonzalez 1997, Pakhomov et al. 2000). Ice cover can also influence community development through its impact on food availability (Mackintosh 1934, Atkinson \& Shreeve 1995, Burghat et al. 1999, Quetin \& Ross 2003, Ward et al. 2004). The development of blooms of large diatoms is often crucial for enabling many species of calanoid copepods and Antarctic krill to maximise growth and reproductive rates (Ross et al. 2000, Shreeve et al. 2002), and changes in phytoplankton properties, expressed either as biomass, size or measures of phytoplankton quality, are also often associated with such faunal discontinuities (Shreeve et al. 2002, Ward et al. 2005).

Understanding the nature of the constraints on Southern Ocean plankton community development and allied seasonal and interannual variability will become increasingly important if we are to identify secular change against background variability. As well as a requirement to document structure over large spatial and temporal scales there is also a need to assess the impacts of physical features such as frontal zones and variable ice cover on production processes. The data presented in this paper were collected during a survey that formed part of the UK's Southern Ocean GLOBEC initiative, which was to examine the large-scale population processes among krill and copepods within the Scotia Sea. Our objectives were to characterise spatial and temporal variability in community structure and development across the area and assess how this variation reflected that of other environmental properties. We compare our present results with those of a 4-ship survey centred on the Scotia Sea and undertaken in early 2000 when ice conditions were dramatically different.

\section{MATERIALS AND METHODS}

Between 8 January and 9 February 2003 as part of cruise JR82 on board RRS 'James Clark Ross', 8 zig-zag transects were run across the Scotia Sea commencing at a position north of Elephant Island and traversing eastwards (Fig. 1). Fifty-five stations were located along the transects at $60 \mathrm{~nm}$ intervals, and at each a full depth CTD cast was carried out followed by vertical Bongo net deployments to $400 \mathrm{~m}$. A further 6 stations located within a mesoscale box straddling the shelf break to the northwest of South Georgia were also sampled. Here CTDs were deployed to $1000 \mathrm{~m}$ in the deeper parts of the box or near bottom over the shelf. Bongo net deployments were to a depth of $200 \mathrm{~m}$ at these 6 stations.

Phytoplankton. Water for analysis of chlorophyll $a$ (chl $a$ ) and phaeopigments, size-fractionated chl $a$ and nutrients was obtained from standard depths (ca. 20,40, $60,80,100,125,150$ and $200 \mathrm{~m}$, and a further 4 evenly spaced depths sampled between $200 \mathrm{~m}$ and the bottom of the cast) at each of the 61 stations using a Seabird 911+ CTD and carousel sampler equipped with twelve 101 Niskin bottles (see Korb \& Whitehouse 2004 for details). Additional samples were obtained from the ship's nontoxic seawater supply located 6 to $7 \mathrm{~m}$ below the sea surface as the CTD was surfacing. Size-fractionated chl a was measured on water samples from a depth of $20 \mathrm{~m}$ by passage through a series of $47 \mathrm{~mm}$ polycarbonate filters $(12,2$ and $0.2 \mu \mathrm{m})$. Thus pico-, nano- and microphytoplankton were represented by the 0.2 to $2 \mu \mathrm{m}, 2$ to $12 \mu \mathrm{m}$ and $>12 \mu \mathrm{m}$ size fractions. Macronutrient concentrations were determined using a Technicon segmented flow analyser (Whitehouse 1997).

Species composition representative of the upper mixed layer was determined at each station from water samples collected at $20 \mathrm{~m}$ and preserved in $1 \%$ acid Lugols solution. Microplankton were enumerated by use of the Utermöhl (1958) technique. Sample solutions 


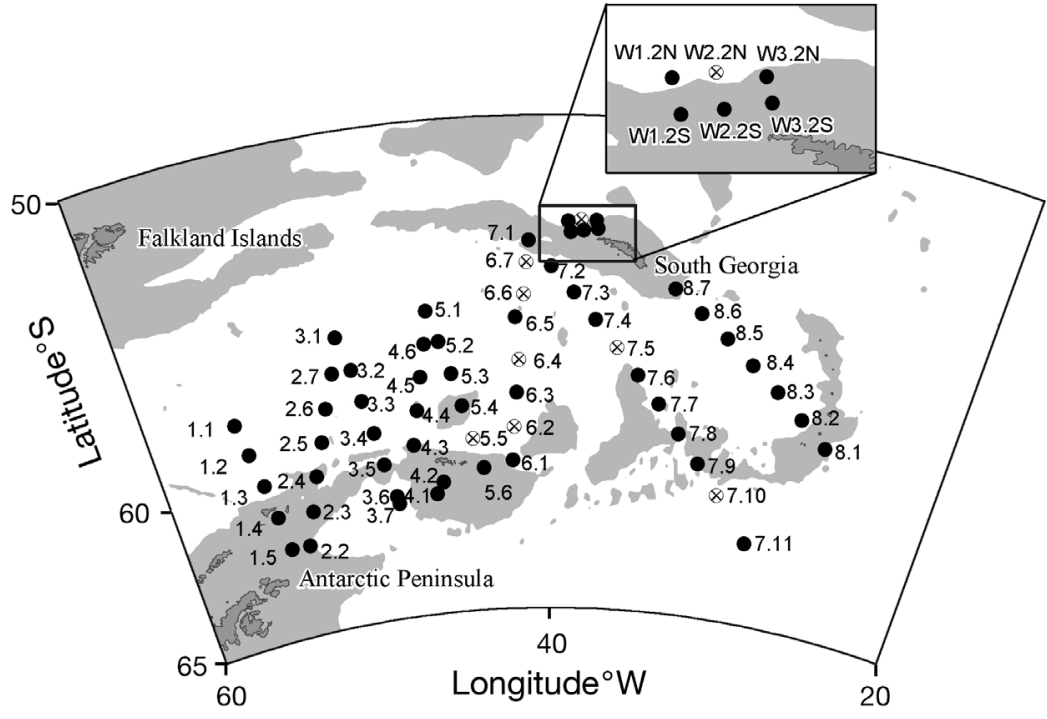

Fig. 1. Scotia Sea study area showing 61 station positions worked during cruise JR82. Bongo nets were worked at all stations and Longhurst-Hardy Plankton Recorder (LHPR) hauls were additionally made at stations shown with crosshairs. Transects were run from west to east. Station identifiers shown relate to transect number first followed by station number. Transect 2 commenced at Stn 2.2 and not 2.1, which lay further south in ice-covered waters and was not sampled. Grey tones represent the $2500 \mathrm{~m}$ isobath in this and subsequent figs

were left to settle in $50 \mathrm{ml}$ chambers for at least $24 \mathrm{~h}$ before analysis of selected microplankton taxa by inverted microscopy. Sixteen selected categories were examined on either 2 or 3 perpendicular transects across the whole slide on $100 \times$ magnification. The categories were chosen on the basis of the dominance of the $>12 \mu \mathrm{m}$ microplankton and their ease of identification. Species counted ranged in size from $\sim 5$ to $200 \mu \mathrm{m}$.

Mesozooplankton. At each station a motioncompensated Bongo net (mouth diameter opening $61 \mathrm{~cm}$, net mesh $200 \mu \mathrm{m}$ ) with 2 solid cod-ends was deployed from the surface to $400 \mathrm{~m}$ and then hauled vertically back onboard the stationary vessel. Upon recovery the contents of one cod-end were immediately diluted with surface seawater at ambient temperature for sorting of live material. To investigate production processes and understand how they varied spatially, we required species and stages that we were confident would be present over much of the survey area. Therefore, Calanoides acutus and Rhincalanus gigas females were chosen for egg production experiments and carbon (C) mass determinations and additionally stages CIV and $\mathrm{CV}$ of $C$. acutus for $\mathrm{C}$ mass determination. Female copepods were sorted and incubated in groups of 10 for $24 \mathrm{~h}$ to determine egg production rates (EPR see Ward \& Shreeve 1995 for further details). Females were then removed, rinsed briefly in ammonium formate and placed in pre-weighed ultra lightweight tin foil capsules. Additionally, $230 \mathrm{CIV}$ and CV C. acutus from each station were frozen for $\mathrm{C}$ mass determination. Samples were frozen at $-80^{\circ} \mathrm{C}$ and subsequently dried at $60^{\circ} \mathrm{C}$ onboard ship within 1 wk of collection. They were then transferred in a sealed container to the UK where they were again dried at $60^{\circ} \mathrm{C}$ to constant weight. Dry mass was measured on a Mettler MT5 balance to an accuracy of $\pm 1 \mu \mathrm{g}$. Whole samples were then analysed for $\mathrm{C}$ and $\mathrm{N}$ using a Fisons EA 1108 elemental analyser using acetanilide as a standard.

The contents of the second cod-end were preserved in $10 \%(\mathrm{v}: \mathrm{v})$ formalin in seawater for community analysis in the UK, where they were divided into appropriate aliquots with a Folsom plankton splitter and examined under a binocular microscope. Zooplankton were identified to species and stage or higher taxonomic categories and enumerated. An average number of between 1000 and 1500 individuals were counted in each sample.

Fatty acid and POC analyses. Seawater samples (between 1.2 and 3.6 l) collected at $20 \mathrm{~m}$ for particulate organic carbon (POC) and total fatty acid (TFA) analysis were filtered onto pre-ashed GF/F filters. Those for TFA analysis were placed in chloroform:methanol (2:1 v/v) and both were then stored at $-80^{\circ} \mathrm{C}$ until analysis. After the addition of an internal fatty acid standard (21:0) lipids were extracted according to Folch et al. (1957). Fatty acid methyl esters were prepared in methanol containing $1 \%$ sulphuric acid and transmethylated at $50^{\circ} \mathrm{C}$ for $16 \mathrm{~h}$ (Christie 1982). After purification by thin-layer chromatography, fatty acid methyl esters were dissolved in hexane at a concentration of $1 \mathrm{mg} \mathrm{ml}^{-1}$ and analysed on a Carlo Erba Trace 2000 gas chromatograph equipped with a ZBWAX fused silica capillary column $(30 \mathrm{~m} \times 0.32 \mu \mathrm{m})$. Hydrogen was used as the carrier gas, and fatty acids were identified by comparison with a well-characterized marine fish oil.

Similar quantities of seawater for POC analysis were also filtered onto pre-ashed filters and stored at $-80^{\circ} \mathrm{C}$. In the UK samples were acidified under an atmosphere of fuming hydrochloric acid for $24 \mathrm{~h}$ and then dried in a vacuum desiccator for $24 \mathrm{~h}$. Elemental $\mathrm{C}$ and $\mathrm{N}$ were determined in 3 replicate subsamples as for the above copepod samples.

LHPR sampling. At 8 stations (Fig. 1) a LonghurstHardy Plankton Recorder (LHPR) equipped with a $200 \mu \mathrm{m}$ mesh net and $38 \mathrm{~cm}$ diameter nose cone was rapidly deployed to $1000 \mathrm{~m}$. The net was allowed to stabilise at depth and was then fished to the surface, 
hauling at a rate of $\sim 30 \mathrm{~m} \mathrm{~min}^{-1}$. The LHPR was programmed with a gauze advance time of $90 \mathrm{~s}$ and fished at a ship's speed of 3.5 to 4 knots. In this way the ascent profile contained 45 to 60 patches with an average depth resolution of $\sim 20 \mathrm{~m}$, representing approx. $18 \mathrm{~m}^{3}$ filtered per patch. Upon recovery the gauzes were cut into individual patches and frozen at $-20^{\circ} \mathrm{C}$. In the UK gauzes were thawed and fixed in formalin and the copepodite stages of 2 of the biomass dominant species (Calanoides acutus, Rhincalanus gigas) were enumerated. Data were standardised to ind. $\mathrm{m}^{-2}$.

The mean stage of the population $(\mathrm{S})$ was estimated according to the equation where CI,CII...CVI represent successive copepodite stages, $n$ is the number of individuals within each stage and $N$ is the overall abundance of all stages combined.

$$
\mathrm{S}=\frac{n \mathrm{CI}+2 n \mathrm{CII}+\ldots+6 \mathrm{CVI}}{\mathrm{N}}
$$

Data analysis. Phytoplankton cell counts and mesozooplankton data were initially analysed with the statistical package PRIMER 5 (Primer-E). Standardised data in the form of phytoplankton cell counts (ind. $50 \mathrm{ml}^{-1}$ ) and mesozooplankton abundance (ind. $\mathrm{m}^{-2}$ ) were double-root-transformed and subjected to $q$-type cluster analysis to group stations based on the BrayCurtis similarity and group average linkage classification (Field et al. 1982). The treatment of the mesozooplankton data prior to running PRIMER analyses differed from that of the phytoplankton cell count dataset in that rare species and stages were not removed from the data matrix, and species stages were not aggregated into higher groupings, although data were standardised to ind. $\mathrm{m}^{-2}$ (0 to $400 \mathrm{~m}$ ) and doubleroot-transformed to normalise abundance. This approach was dictated largely by the fact that previous research (Pakhomov et al. 2000, Ward et al. 2004) indicated that differences between zooplankton communities are very often the result of changes in species abundance rather than species composition and that variable abundance, as well as being attributable to changing distribution across a species range, can often result from differences in rates and timing of recruitment across that range. By distinguishing between ontogenetic stages rather than aggregating them under species headings we wished to see how station groupings differed in terms of community development.

Non-metric multi-dimensional scaling (MDS) was also performed to allow relationships between groups to be assessed. Its purpose is to represent the samples as points in low-dimensional space (2D) such that the relative distances from all the points are in the same rank order as the relative dissimilarities of the samples (as calculated by Bray-Curtis coefficients). The starting configuration in this instance is a random set of points. There is no guaranteed method of ensuring that a global minimum stress has been reached; therefore the algorithm dictates that the analysis is repeated several times (in this instance 25 times) starting with different random positions of samples. The stress levels indicates how faithfully the high-dimensional relationships among the samples are represented in the $2 \mathrm{D}$ plot with a value of $\sim 0.1$ indicating a good representation of the data.

The SIMPER (similarity percentages) routine was also performed on both datasets. SIMPER examines how much each species/taxon contributes to the average sample similarity within and dissimilarity between groups (Clarke \& Warwick 2001). We also used the RELATE procedure (non-parametric Mantel-type coefficients) to compare the 2 multi-variate representations and BIO-ENV, a routine that calculates a measure of agreement between 2 (dis)similarity matrices, on the mesozooplankton data matrix and another containing information on environmental variables measured at each station (see Table 7 and Results section for details of variables included). Within the analysis, rank correlation $(\rho)$ of the matching elements was carried out with combinations of the environmental variables being considered at steadily increasing levels of complexity. In this way an optimal subset of environmental variables that 'best explains' the biotic structure is identified. A value of $\rho=0$ would imply an absence of any match between the 2 patterns, but typically values of $\rho$ will be positive with a value of +1 being a perfect match (Clarke \& Ainsworth 1993).

The relationship between $\mathrm{C}$ mass, abundance and EPR data collected at each station and a suite of 9 potential predictor variables (see Table 9 and 'Results' for full details) was examined using best subsets regression. Response and predictor variables were log-transformed where necessary to linearise the relationship, stabilise variability, and reduce skewness. The Akaike Information Criterion with small-sample adjustment $\left(\mathrm{AIC}_{\mathrm{c}}\right)$ was used for model selection (Burnham \& Anderson 2002). Low values of $\mathrm{AIC}_{\mathrm{c}}$ indicate parsimonious models with good fit and few parameters. For presentation, values of $\mathrm{AIC}_{\mathrm{c}}$ for different models are expressed relative to the smallest value as a difference $\Delta=\mathrm{AIC}_{\mathrm{c}}-\min \left(\mathrm{AIC}_{\mathrm{c}}\right)$. Models within about 2 units of the minimum are considered as competing models in a statistical sense (Burnham \& Anderson 2002). Spatial autocorrelation was examined using the variogram of the standardised residuals from the fitted model (Cressie 1993). The residuals at locations $i$ and $j$ along a particular transect were denoted by $r_{i}$ and $r_{j}$, respectively, with the corresponding distance between locations denoted by $d_{i j}$. The variogram was formed by plotting the square of the difference between the residuals $V_{i j}=\left(r_{i}-r_{j}\right)^{2}$ against $d_{i j}$ over all 
pairs of residuals. An increase of $v_{i j}$ with $d_{i j}$ indicates a pattern of autocorrelation that decreases with distance between locations. Analyses were implemented using the statistical software package MINITAB v.13 (Pennsylvania State University).

Sea-ice cover. Sea-ice-concentration data were calculated from the U.S. Defense Meteorological Satellite Program's Special Sensor Microwave Imager passive microwave data by the National Oceanic and Atmospheric Agency/National Centers for Environmental Prediction (NOAA/NCEP). These data were first previewed as the northern extent of the $15 \%$ ice concentration. Spurious values (for example from icebergs) were removed before plotting the monthly positions of the northern extent of $15 \%$ sea-ice concentration in the geographical information system package ArcGIS8.2 (ESRI).

\section{RESULTS}

\section{Physical characteristics and position of fronts}

CTD potential temperature-salinity data were used to characterise the different water masses occurring within the Scotia Sea (Fig. 2). While there was a clear distinction between waters to the south of the Southern Boundary of the Antarctic Circumpolar Current Front (SB) and waters to the north of the Southern Antarctic Circumpolar Current Front (SACCF) compared with the rest of the survey stations, there was a degree of overlap in the TS characteristics at the SACCF. Here, nutrient and oxygen data were used to further discern the position of the SACCF (Sievers \& Nowlin 1984). The major frontal jets were generally orientated in a southwest-to-northeast direction through the study site, with meandering and eddy-shedding particularly evident within the mid-survey area (Fig. 2). The Polar Front (PF) was not traversed, although water in the extreme northwest of the survey area may have originated from north of the front. At the southern extremities of the survey, Weddell Front and Weddell Scotia Confluence characteristics were evident only intermittently. Within the Scotia Sea typical Antarctic surface- water profiles were found at 25 of the 27 stations occupied between the northernmost stations (excluding casts downstream of South Georgia) and the SB (median $\mathrm{T} \min 70 \mathrm{~m}$ ).

\section{Microplankton community structure}

Cluster and MDS analysis identified 4 groups of stations and 1 outlier (Table 1, Fig. 3). Median values of chl a and other chemical indices relating to the phytoplankton characterising each station group are presented in Table 2 and size-fractionated percentages in Table 3.

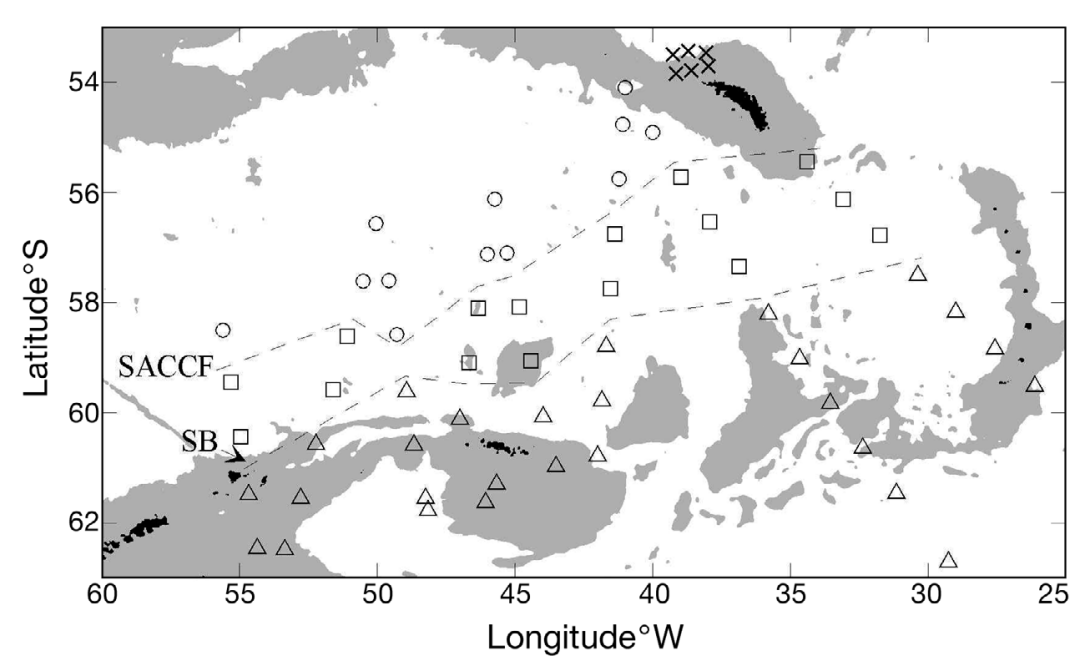

Fig. 2. Water mass distribution within Scotia Sea during cruise JR82. $\times=$ South Georgia Modified Shelf water, $\mathrm{O}=$ water lying to north of the southern Antarctic Circumpolar Current Front (SACCF), $\square=$ water lying between SACCF and the Southern Boundary of the Antarctic Circumpolar Current Front (SB), $\Delta=$ water lying to south of SB. Approximate frontal positions indicated by dashed lines

Table 1. Average cell count abundance (no. ind. $50 \mathrm{ml}^{-1}$ ) within phytoplankton station groupings of species and taxa that SIMPER analysis indicated contributed most to within-group similarity and between-group dissimilarity. Highest value for each species/taxa in bold. Species have been arranged in order of total abundance across all groups with respect to major taxonomic groupings. Species taxonomy in accordance with Scott \& Marchant (2005). Highest value for each species/taxon in bold

\begin{tabular}{|lrrrr|}
\hline Species/taxon & \multicolumn{5}{c|}{$\begin{array}{c}\text { Abundance no. ind 50 } \mathrm{ml}^{-1} \\
\text { Group 1 } \\
(\mathrm{n}=6)\end{array}$} & $\begin{array}{c}\text { Group 2 } \\
(\mathrm{n}=17)\end{array}$ & $\begin{array}{c}\text { Group 3 } \\
(\mathrm{n}=24)\end{array}$ & $\begin{array}{c}\text { Group 4 } \\
(\mathrm{n}=14)\end{array}$ \\
& & & & \\
& $\mathbf{1 6 1 4 3}$ & 0 & 0.4 & 148 \\
Eucampia antarctica & 735 & 96 & 657 & $\mathbf{8 0 9 6}$ \\
Nitzschia/Pseudonitzschia spp. & 544 & 52 & 785 & $\mathbf{6 2 5 7}$ \\
Fragilariopsis Kerguelensis & 748 & 24 & 252 & $\mathbf{6 3 7 9}$ \\
Chaetoceros spp. & $\mathbf{3 6 1 9}$ & 19 & 165 & 1336 \\
Thallasiosira sp. & $\mathbf{1 9 8 6}$ & 291 & 744 & 1438 \\
Thallasionema/Fragilariopsis spp. & 27 & 0.6 & 120 & $\mathbf{1 2 5}$ \\
Rhizosolenia sp. & 2462 & 610 & 787 & $\mathbf{2 7 4 9}$ \\
Small dinoflagellates & $\mathbf{1 7 2}$ & 50 & 57 & 47 \\
Small ciliates & & & &
\end{tabular}



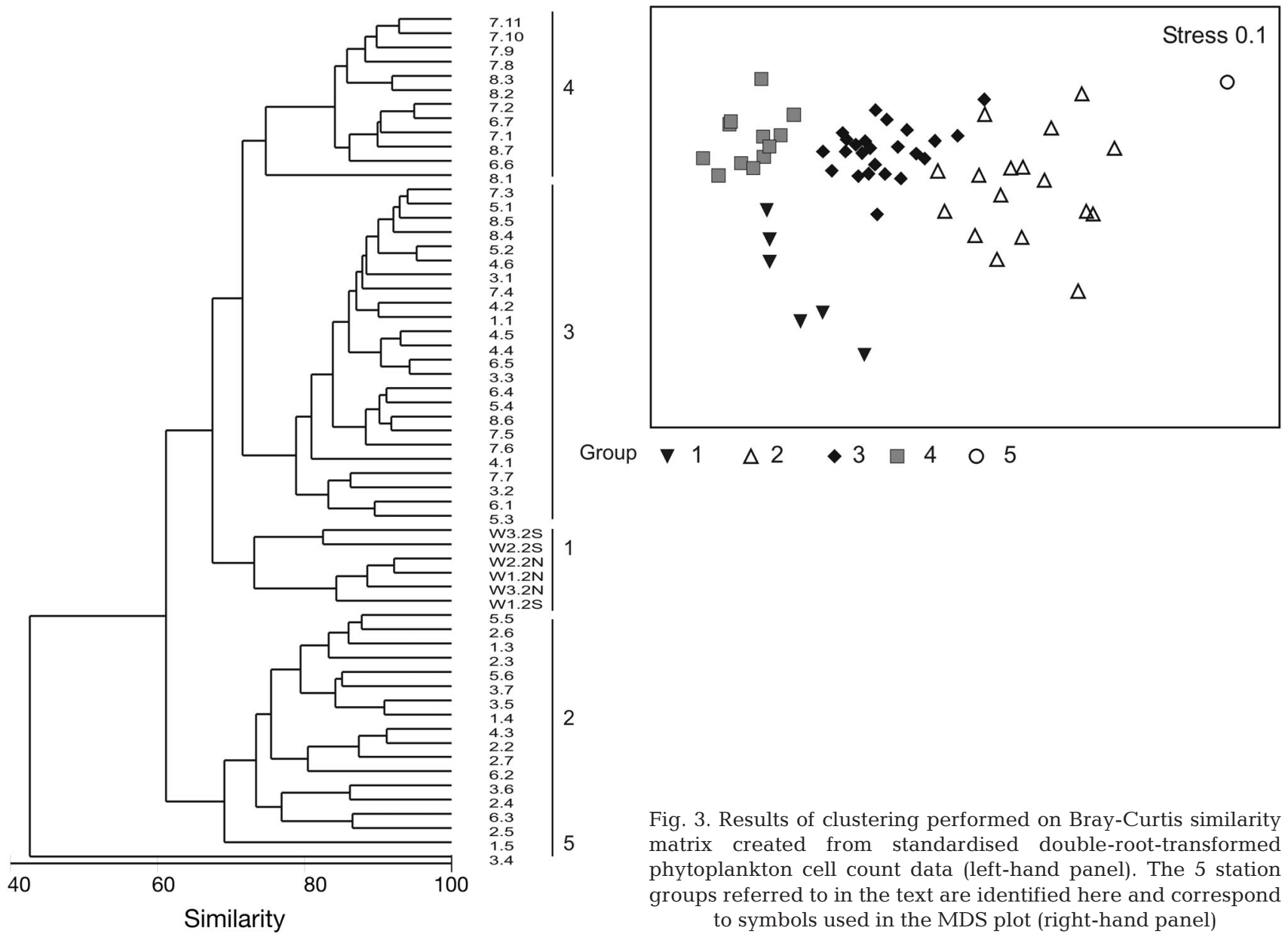

Table 2. Median values (upper and lower quartile values) for chl $a$, POC, particulate $\mathrm{C}: \mathrm{N}$ and total fatty acids with respect to phytoplankton station groups

\begin{tabular}{|lcccc|}
\hline & $\begin{array}{c}\text { Group 1 } \\
(\mathrm{n}=6)\end{array}$ & $\begin{array}{c}\text { Group 2 } \\
(\mathrm{n}=17)\end{array}$ & $\begin{array}{c}\text { Group 3 } \\
(\mathrm{n}=24)\end{array}$ & $\begin{array}{c}\text { Group 4 } \\
(\mathrm{n}=14)\end{array}$ \\
\hline $\mathrm{Chl} \mathrm{a}$ & 5.72 & 0.21 & 0.29 & 1.12 \\
$\left(\mathrm{mg} \mathrm{m}^{-2}, 0-100 \mathrm{~m}\right)$ & $(2.91-8.63)$ & $(0.14-0.53)$ & $(0.16-0.49)$ & $0.17-2.34)$ \\
$\mathrm{POC}$ & 146 & 52 & 57 & 91 \\
$\left(\mu \mathrm{g} \mathrm{l}^{-1}, 20 \mathrm{~m}\right)$ & $(115-229)$ & $(42-69)$ & $(41-116)$ & $(67-136)$ \\
$\mathrm{C}: \mathrm{N}$ & 6.00 & 5.44 & 5.44 & 5.60 \\
$($ particulates, 20 m) & $(5.62-6.43)$ & $(5.06-5.70)$ & $(5.26-5.73)$ & $(5.35-5.89)$ \\
Total fatty acids & 153 & 28 & 33 & 96 \\
$\left(\mu \mathrm{g} \mathrm{l}^{-1}, 20 \mathrm{~m}\right)$ & $(119-165)$ & $(22-34)$ & $(22-41)$ & $(68-118)$ \\
\hline
\end{tabular}

tions of transects 3 to 5 and thereafter in the middle portions of transects 6 to 8. Surface chl a was slightly higher $\left(\leq 1.9 \mathrm{mg} \mathrm{m}^{-3}\right)$, although cell counts were modest and no one particular taxon dominated. Whereas the stations in the above groups had clear geographic integrity (Fig. 4), those in Group 4 (14 stations) were distributed along the tops of transects 1, 6, 7 and 8 and additionally comprised the southerly portions of transects 7 and 8 . Here surface chl a was higher $\left(\leq 9 \mathrm{mg} \mathrm{m}^{-3}\right)$ and highest values of Nitzschia/Pseudonitzschia spp., Fragi-

Group 1 comprised 6 stations north of South Georgia where cell counts were high as were surface chl a values (1.9 to $11.4 \mathrm{mg} \mathrm{m}^{-3}$ ). Here Eucampia antarctica was characteristic and almost exclusive to this group. Group 2 (17 stations) was located mainly along the southern portions of the first 6 transects and were characterised by surface chl a values of $\leq 1 \mathrm{mg} \mathrm{m}^{-3}$ and by low overall cell counts. Small dinoflagellates characterised these stations with remaining taxa occurring in low abundance. Group 3 (24 stations) generally occurred at the northern por- lariopsis kerguelensis and Chaetoceros spp. were found. SeaWiFS composites for January indicated that the southerly bloom stations may have been influenced by the retreating ice edge (Korb et al. 2005).

\section{Mesozooplankton}

Four main station groupings were disclosed by the cluster and MDS analysis with a single outlier (Fig. 5). 
Table 3. Mean values of percentage size-fractionated chl a biomass from $20 \mathrm{~m}$ water bottle with respect to phytoplankton station groups (upper and lower quartile values)

\begin{tabular}{|lcccc|}
\hline Size fraction & Group 1 & Group 2 & Group 3 & Group 4 \\
\hline $\begin{array}{l}\text { \% Microphytoplankton } \\
(>12 \mu \mathrm{m})\end{array}$ & 80 & 11 & 40 & 68 \\
& $(70-89)$ & $(2-16)$ & $(15-65)$ & $(49-87)$ \\
\% Nanophytoplankton & 12 & 42 & & 1 \\
$(2-12 \mu \mathrm{m})$ & $(7-16)$ & $(31-52)$ & $(21-43)$ & $(8-27)$ \\
$\%$ Picophytoplankton & 8 & 47 & 28 & 13 \\
$(<2 \mu \mathrm{m})$ & $(4-14)$ & $(39-55)$ & $(12-41)$ & $(4-21)$ \\
\hline
\end{tabular}

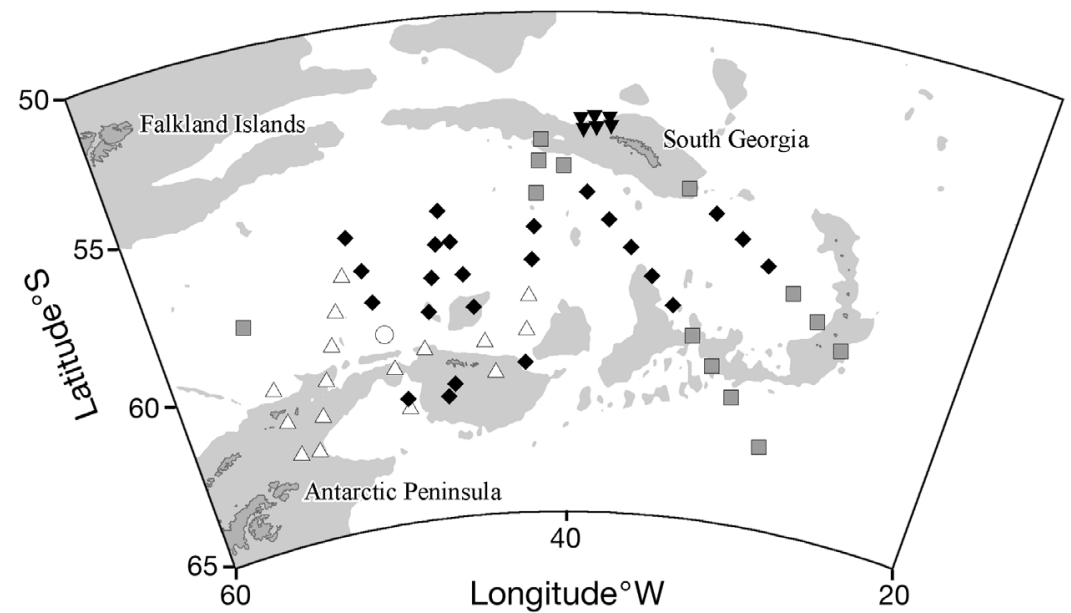

Fig. 4. Geographical distribution of station groups identified in phytoplankton cell count ordination. Symbols correspond to those used in Fig. 3 median abundance of mesozooplankton across groups was $>3$ times greater in Group 1 than in the remaining 3 groups or the outlying single station (Group 5). Overall, copepods accounted for between $77 \%$ and $97 \%$ of total mesozooplankton abundance with large copepods (prosome length $>\sim 1.5 \mathrm{~mm}$ ) proportionately accounting for $<4 \%$ of total abundance (Table 5).

There were also clear differences in the development of large calanoid copepod populations in the top $400 \mathrm{~m}$ over the Scotia Sea. Over-wintered populations of Calanoides acutus (low overall abundance and relatively high number of females) in a pre-recruitment phase characterised almost all of the stations in Group 2, whereas further north and east the spring generation had evidently developed and north of South Georgia was already undergoing a seasonal descent. Such an interpretation is consistent with the findings of Atkinson (1991) and Atkinson et al. (1997) and the life-cycle model developed by Tarling et al. (2004). Details of population vertical distribution are given below in the LHPR section (see below and Fig. 8b). The distribution of Calanus propinquus reflected that of C. acutus with older stages dominating

The station groupings were in modest agreement with those of the microplankton ordination (RELATE analysis $\rho=0.438, p=0.1 \%$ ). Geographical positions of station groups are presented in Fig. 6. Once again Group 1 comprised stations to the north of South Georgia but additionally included stations at the northern end of transects 6 to 8 . The average abundance of the 28 taxa, in this case with stages aggregated within species, which collectively contributed $\geq 2 \%$ of similarity within groups or dissimilarity between groups, as indicated by SIMPER analysis, are presented in Table 4.

Most taxa were present across the entire Scotia Sea, but generally their abundance was highest within station Group 1. Groups 2 and 3 largely paralleled the geographic distribution of the microplankton station groupings and their respective qualities in terms of relative abundance of taxa across groups (Table 1). Group 4 in this case occupied the greater part of transects 6 to 8 rather than being restricted to their extreme ends. One other station comprised an outlier from the main station groupings indicated in Fig. 6. It was located near the ice edge just east of the South Orkneys (Fig. 7) and was characterised by an overall reduction of taxa. The the majority of stations in Group 2, whereas a latitudinal cline was broadly discernible among the remaining stations. For Rhincalanus gigas, which generally spawns later than the other species, the population displayed a clear latitudinal cline with younger stages dominating Group 1 and older stages generally present further south. The mean stage of each species with respect to station group is presented in Table 6 .

Although we were unable to distinguish ontogenetic stages for many of the other copepod species present, the 'catch-all' taxonomic groupings calanoid nauplii and cyclopoid nauplii also showed distribution patterns that reflected those described above with respect to station groupings (Table 4). Krill larvae were present, albeit in relatively low concentrations, in the northern part of the Scotia Sea and along transects 7 and 8 . Highest larval densities (7000 ind. $\mathrm{m}^{-2}$ ) were unusually found in oceanic waters to the northwest of South Georgia (Fig. 9b).

Of the environmental variables used in the BIOENV analysis, latitude was the strongest of the correlates with mesozooplankton community pattern ( $\rho=$ 0.608). Inclusion of phosphate, which was inversely 


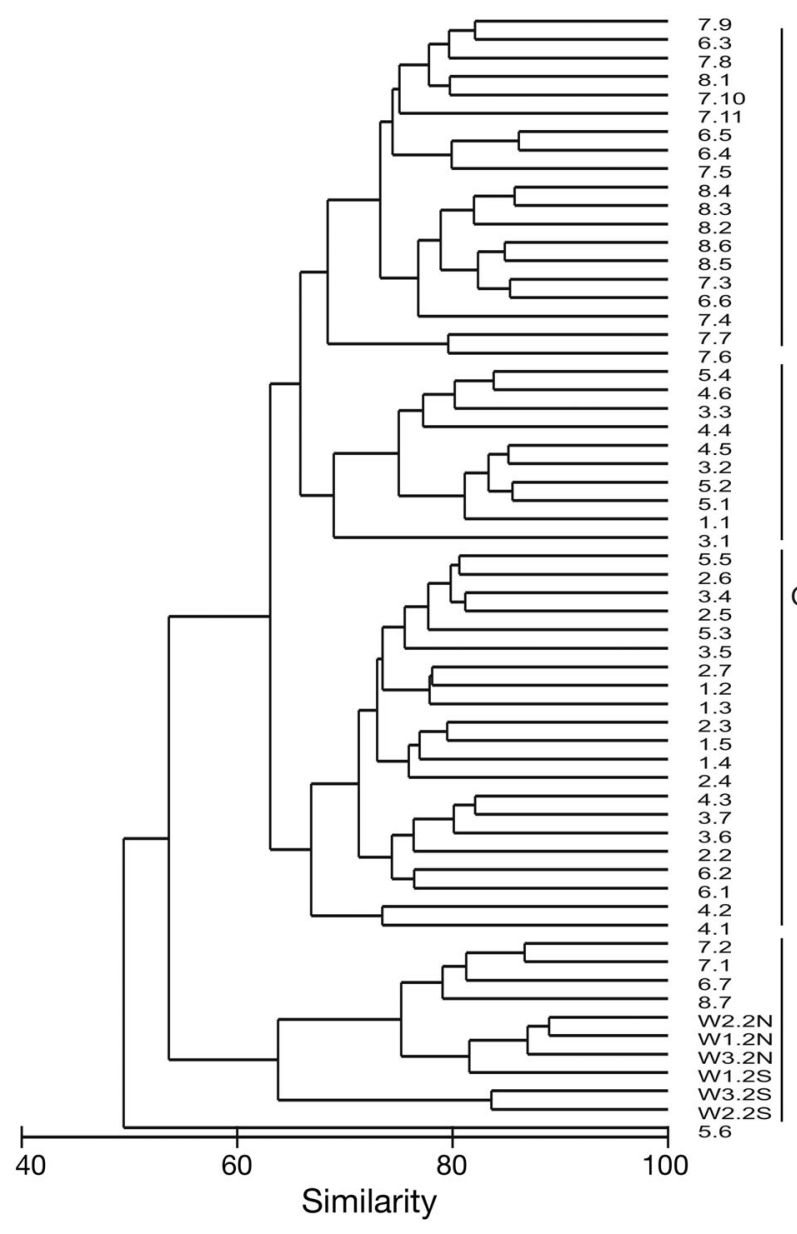

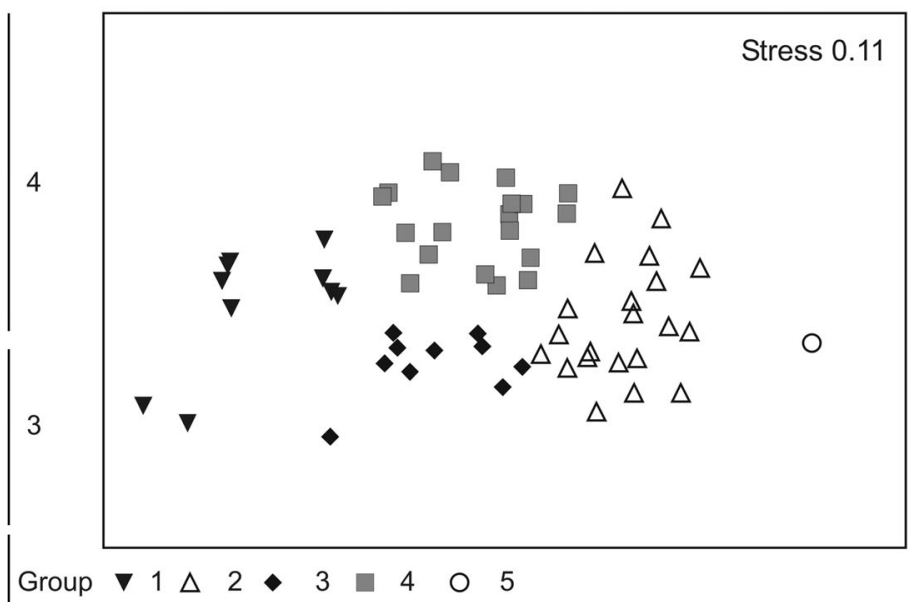

2

Fig. 5. Results of clustering performed on Bray-Curtis similarity matrix created from standardised mesozooplankton data (left-hand panel). The 5 station groups referred to in the text are identified here and correspond to symbols used in the MDS plot (right-hand panel)

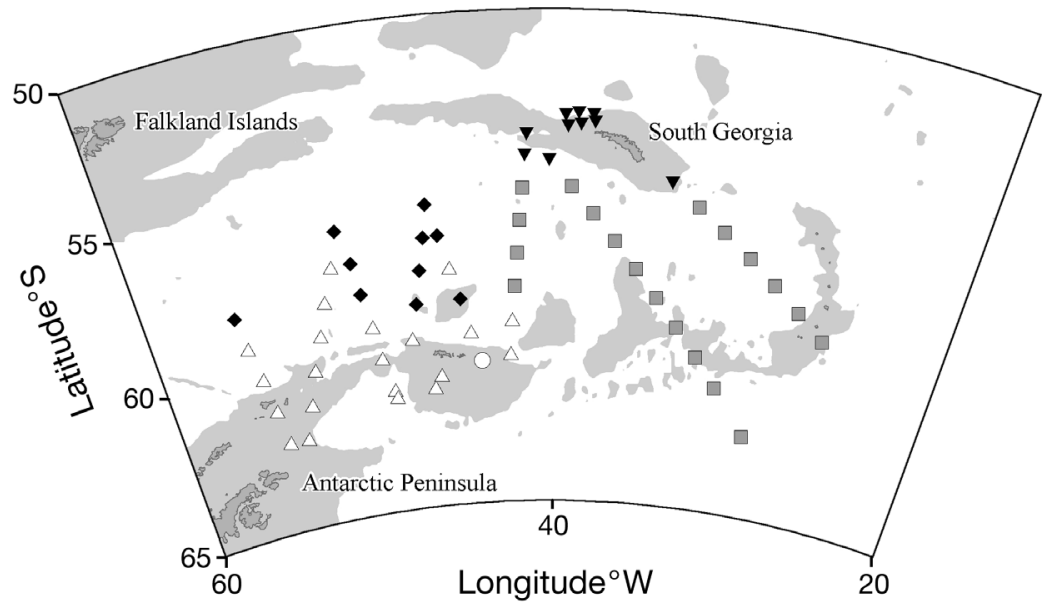

Fig. 6. Geographical distribution of station groups identified in mesozooplankton ordination. Symbols correspond to those used in Fig. 5
0.85, $F=345.95, \mathrm{p}<0.0001)$, substitution of temperature for latitude in the analysis gave a lower rank correlation $(\rho=0.44)$. In contrast with stepwise regression analysis (see below), surface chl a was also a weaker correlate with overall community pattern $(\rho=$ 0.344).

\section{Carbon mass and egg production}

For Calanoides acutus only stations where stages CIV and CV could be attributed with confidence as belonging to the new summer generation were included in the analysis of carbon mass. Stations where low abundance was coupled with a dominance of later related to chl a biomass, increased the rank correlation coefficient ( $\rho=0.642$ ), whilst other variables did nothing to significantly improve the fit (Table 7 ). Although latitude might be considered a proxy for temperature (they were significantly correlated; $\mathrm{R}^{2}=$ stages were excluded because here copepod condition was thought likely to reflect their recent overwintered state rather than the influence of any of the measured environmental variables. Such populations were predominantly found at stations within Group 2. 
Table 4. Average mesozooplankton abundance (ind. $\mathrm{m}^{-2}, 0-400 \mathrm{~m}^{*}$ ) within station groupings of species and taxa that SIMPER analysis indicated contributed most to within-group similarity and between-group dissimilarity. Species have been arranged in order of total abundance across all groups. Highest value for each species/taxon in bold. *Abundance at South Georgia stations sampled in water column of $200 \mathrm{~m}$ (see 'Materials \& methods')

\begin{tabular}{|lrrrr|}
\hline Species/Taxon & $\begin{array}{c}\text { Group 1 } \\
\mathrm{n}=10\end{array}$ & $\begin{array}{r}\text { Group 2 } \\
\mathrm{n}=21\end{array}$ & $\begin{array}{r}\text { Group 3 } \\
\mathrm{n}=10\end{array}$ & $\begin{array}{c}\text { Group } 4 \\
\mathrm{n}=19\end{array}$ \\
\hline Oithona spp. & $\mathbf{3 4 8 2 6 7}$ & 34060 & 63479 & 82854 \\
Cyclopoid nauplii & $\mathbf{4 9 4 0 8}$ & 97 & 268 & 12622 \\
Metridia spp. CI-III & $\mathbf{2 5 5 3 6}$ & 2663 & 7742 & 12259 \\
Oncaea spp. & $\mathbf{1 7 2 5 8}$ & 5310 & 6362 & 13313 \\
Appendicularians & $\mathbf{1 9 4 9 2}$ & 2146 & 9647 & 8835 \\
Microcalanus pygmaeus & 5300 & 10495 & 6502 & $\mathbf{1 2 7 1 6}$ \\
Drepanopus forcipatus & $\mathbf{3 4 6 9 1}$ & 0 & 0 & 0 \\
Ctenocalanus spp. & $\mathbf{2 6 6 7 5}$ & 1542 & 1533 & 1352 \\
Rhincalanus gigas nauplii & $\mathbf{1 7 6 9 6}$ & 27 & 657 & 501 \\
Metridia spp. CIV-VI & $\mathbf{8 9 6 8}$ & 607 & 1602 & 3054 \\
Calanoid nauplii & $\mathbf{6 4 6 7}$ & 320 & 864 & 4620 \\
Calanus simillimus & $\mathbf{5 5 9 0}$ & 54 & 1920 & 22 \\
Calanoides acutus & $\mathbf{3 0 1 7}$ & 488 & 1556 & 1654 \\
Limacina spp. & $\mathbf{3 8 1 1}$ & 21 & 712 & 911 \\
Chaetognatha & 808 & 585 & $\mathbf{1 4 2 2}$ & 927 \\
Rhincalanus gigas & $\mathbf{2 1 4 4}$ & 96 & 1010 & 216 \\
Pelagobia longicirrata & $\mathbf{2 5 8 4}$ & 107 & 0 & 575 \\
Calanus propinquus & $\mathbf{1 6 2 1}$ & 29 & 140 & 1333 \\
Ostracoda & 506 & 688 & 368 & $\mathbf{1 0 1 3}$ \\
Euchaeta antarctica & 285 & 360 & $\mathbf{3 8 0}$ & 187 \\
Thysanoessa spp. Calyptopes & $\mathbf{3 9 4}$ & 101 & 340 & 122 \\
Clausocalanus brevipes & 294 & 0 & 281 & 0 \\
Heterorhabdus spp. & $\mathbf{1 9 7}$ & 106 & 123 & 115 \\
Thysanoessa spp. & $\mathbf{2 5 2}$ & 11 & 189 & 41 \\
Scolecithricella spp. & 96 & 51 & 79 & $\mathbf{2 4 9}$ \\
Scolecithricella minor & 128 & 33 & 99 & $\mathbf{1 5 3}$ \\
Gaidius spp. & 33 & 23 & 49 & $\mathbf{1 2 3}$ \\
Spinocalanus spp. & 29 & 20 & 70 & $\mathbf{9 0}$ \\
\hline
\end{tabular}

Carbon masses of stages CIV and CV Calanoides acutus and female Rhincalanus gigas were highest in zooplankton Group 1 and lowest in Groups 2 and 3 (Table 8). In contrast female $C$. acutus were absent from Group 1 stations and their $\mathrm{C}$ mass was some 4 to 5 times greater in Group 4 than in others. Egg production rates for $R$. gigas were also highest in Group 1 and lowest in Group 2, whereas the highest EPRs for $C$. acutus were recorded at Group 4 stations, particularly those lying towards the southern end of transect 7 . The low C mass values observed for all stages of C. acutus within Stn Group 2 reflects the fact that at the majority of stations in this grouping the population was in an overwintered state and had not commenced recruitment. Of the remaining station groups the new generation dominated all stations in Groups 1, 8 of 9 in Stn Group 3 and at 14 of 19 in Stn Group 4.

For Calanoides acutus CIV, the most parsimonious fit was a single-variable model comprising \% Chlorophyll (2 to $12 \mu \mathrm{m})$. Two-variable models that in addition included either log TFA or latitude were also considered plausible models (Table 9). For stage CV,
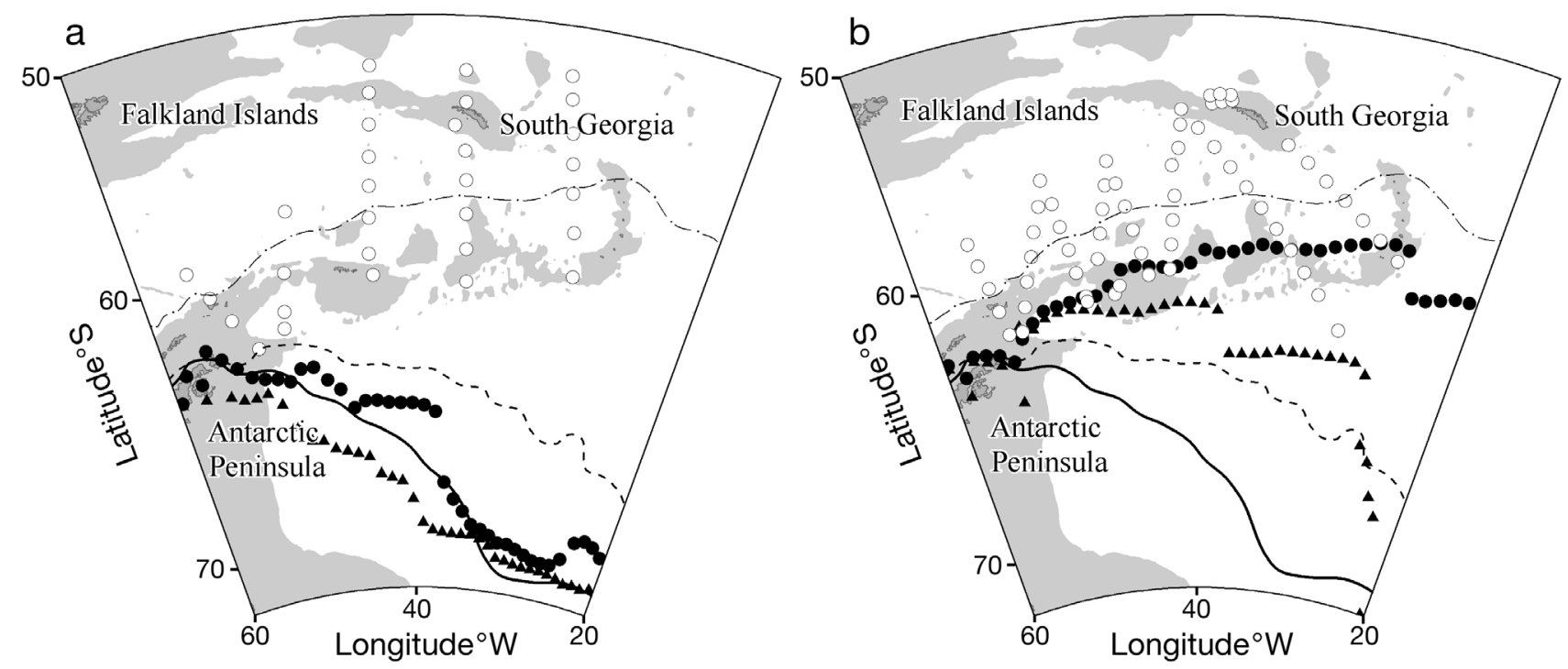

Fig. 7. Mean positions of $15 \%$ ice edge during January and February (a) 2000 and (b) 2003 in relation to 25 yr monthly mean position. The dashed line represents the $25 \mathrm{yr}$ average position during January and the solid line February. Actual positions during January $(\bullet)$ and February $(\boldsymbol{\bullet})$ are shown. $(\mathrm{a}, \mathrm{b}) 25 \mathrm{yr}$ average for August is shown as the most northerly broken line. Details on calculation of ice edge are given in 'Materials and methods' 
Table 5. Median abundance (ind. $\mathrm{m}^{-2}, 0-400 \mathrm{~m}$ plus upper and lower quartile values) of mesozooplankton, large (adult of species $>1.5 \mathrm{~mm}$ ) and small copepods (adult of species $<1.5 \mathrm{~mm}$ ) with respect to mesozooplankton station group. Copepod abundance as a percentage of total zooplankton numbers is also shown

\begin{tabular}{|c|c|c|c|c|c|}
\hline & $\begin{array}{l}\text { Group } 1^{\mathrm{a}} \\
(\mathrm{n}=10)\end{array}$ & $\begin{array}{l}\text { Group } 2 \\
(\mathrm{n}=21)\end{array}$ & $\begin{array}{l}\text { Group } 3 \\
(\mathrm{n}=10)\end{array}$ & $\begin{array}{l}\text { Group } 4 \\
(\mathrm{n}=19)\end{array}$ & $\begin{array}{l}\text { Group } 5 \\
(\mathrm{n}=1)\end{array}$ \\
\hline Mesozooplankton & $\begin{array}{c}5.1 \times 10^{5} \\
\left(3.5 \times 10^{5}-8.4 \times 10^{5}\right)\end{array}$ & $\begin{array}{c}6.3 \times 10^{4} \\
\left(4.1 \times 10^{4}-7.9 \times 10^{4}\right)\end{array}$ & $\begin{array}{c}1.06 \times 10^{5} \\
\left(7.3 \times 10^{4}-1.66 \times 10^{5}\right)\end{array}$ & $\begin{array}{c}1.5 \times 10^{5} \\
\left(1.01 \times 10^{5}-2.4 \times 10^{5}\right)\end{array}$ & $3.7 \times 10^{4}$ \\
\hline Large copepods & $\begin{array}{c}1.7 \times 10^{4} \\
\left(1.08 \times 10^{4}-5.7 \times 10^{4}\right)\end{array}$ & $\begin{array}{c}1.2 \times 10^{3} \\
(791-1,547)\end{array}$ & $\begin{array}{c}4.3 \times 10^{3} \\
\left(1.9 \times 10^{3}-7.6 \times 10^{3}\right)\end{array}$ & $\begin{array}{c}2.9 \times 10^{3} \\
\left(22.3 \times 10^{3}-6.7 \times 10^{3}\right)\end{array}$ & 0 \\
\hline Small copepods & $\begin{array}{c}3.9 \times 10^{5} \\
\left(2.8 \times 10^{5}-6.9 \times 10^{5}\right)\end{array}$ & $\begin{array}{c}5.7 \times 10^{4} \\
\left(3.7 \times 10^{4}-7 \times 10^{4}\right)\end{array}$ & $\begin{array}{c}9.1 \times 10^{4} \\
\left(6.5 \times 10^{4}-1.33 \times 10^{5}\right)\end{array}$ & $\begin{array}{c}1.4 \times 10^{5} \\
\left(7.7810^{4}-1.8 \times 10^{5}\right)\end{array}$ & $3.6 \times 10^{4}$ \\
\hline $\begin{array}{l}\text { Copepods as \% of } \\
\text { total zooplankton }\end{array}$ & 84 & 92 & 87 & 77 & 97 \\
\hline
\end{tabular}
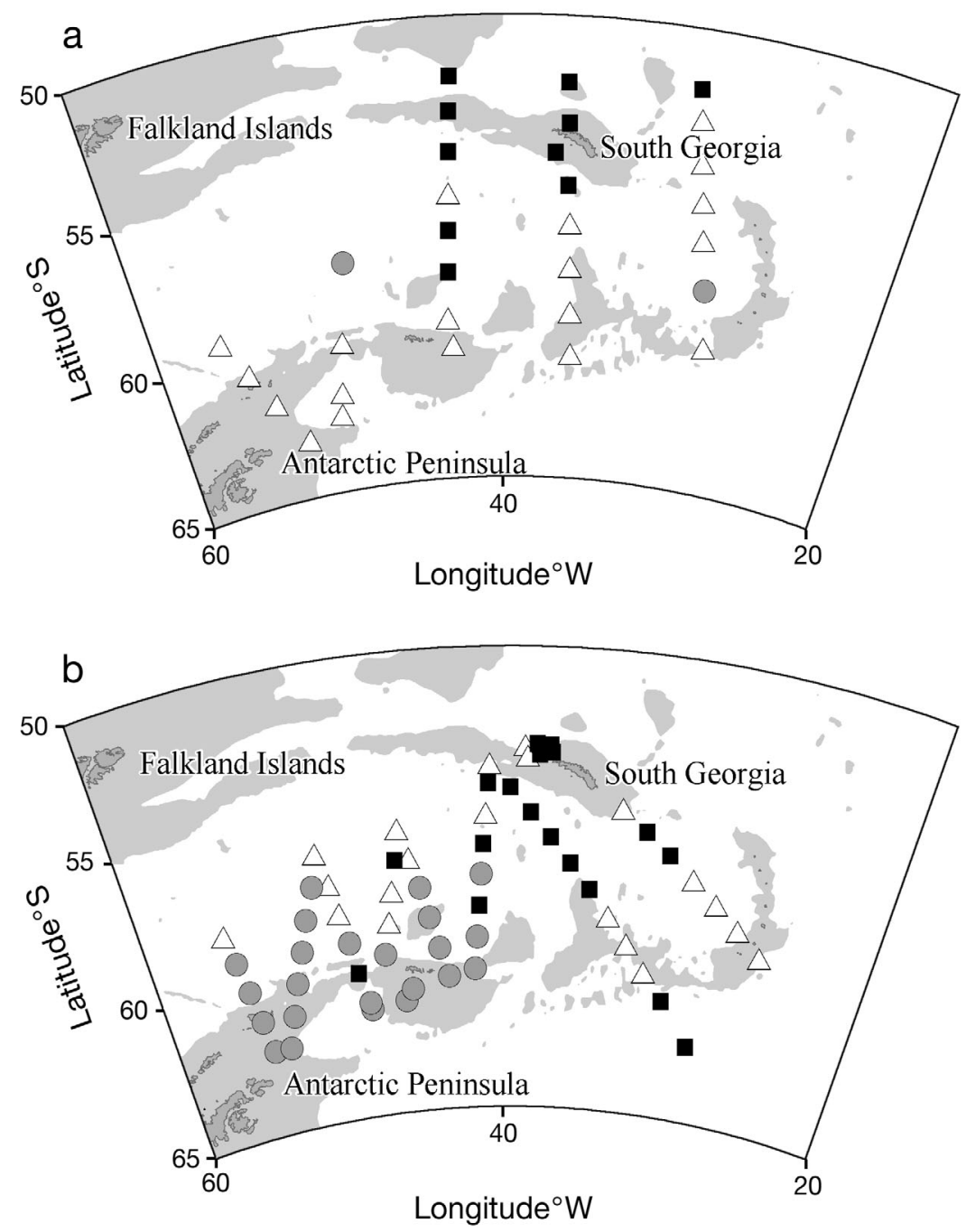

Fig. 8. Calanoides acutus. Relative ages of population at each station during (a) 2000 and (b) 2003. $\Delta=$ mean age CI-CIII, $\mathbf{\square}=$ mean age CIV, $\bullet=$ mean age $\mathrm{CV}-\mathrm{VI}$ $\log$ surface chl a and latitude was considered most appropriate, whereas carbon mass of Rhincalanus gigas females was found to be strongly associated with log TFA and $\mathrm{NO}_{3}$, which are indirectly measures of food quantity, quality and past production levels. The predictors for mesozooplankton abundance indicate positive relationships with \% chl >12 $\mu \mathrm{m}$ and $\log \mathrm{POC}$ and negative relationships with $\mathrm{PO}_{4}$ and latitude, the latter 2 reflecting the pool of unused $\mathrm{PO}_{4}$ as one moves further south. EPR of $C$. acutus was also complexly related to measures of food abundance (\% chl > $12 \mu \mathrm{m}$ and $\log$ TFA) as well as nutrients $\left(\mathrm{NO}_{3}\right.$ in this instance) and latitude. In contrast, EPRs of $R$. gigas were weakly related only to log POC.

\section{LHPR hauls}

The profiles, mostly taken to the east of the South Orkneys towards the end of January, included stations that a month earlier would have been covered in ice. All were taken in icefree areas, although at varying distances from the ice edge, and all bar one were sampled within a $13 \mathrm{~d}$ period (Table 10). Populations of both Calanoides acutus and Rhincalanus gigas lay deeper in the water column with increasing latitude, and younger copepodite stages were generally pre- 
Table 6. Mean stage of 4 main biomass dominant species of calanoid copepod with respect to zooplankton station group. See 'Materials and methods' for details of calculation

\begin{tabular}{|lcccc|}
\hline Species & Group 1 & Group 2 & Group 3 & Group 4 \\
\hline Calanoides acutus & 4.13 & 5.34 & 3.68 & 3.73 \\
Rhincalanus gigas & 2.80 & 4.99 & 4.64 & 5.06 \\
Calanus simillimus & 3.08 & 2.68 & 2.55 & 2.26 \\
Calanus propinquus & 3.66 & 4.62 & 3.50 & 2.19 \\
\hline
\end{tabular}
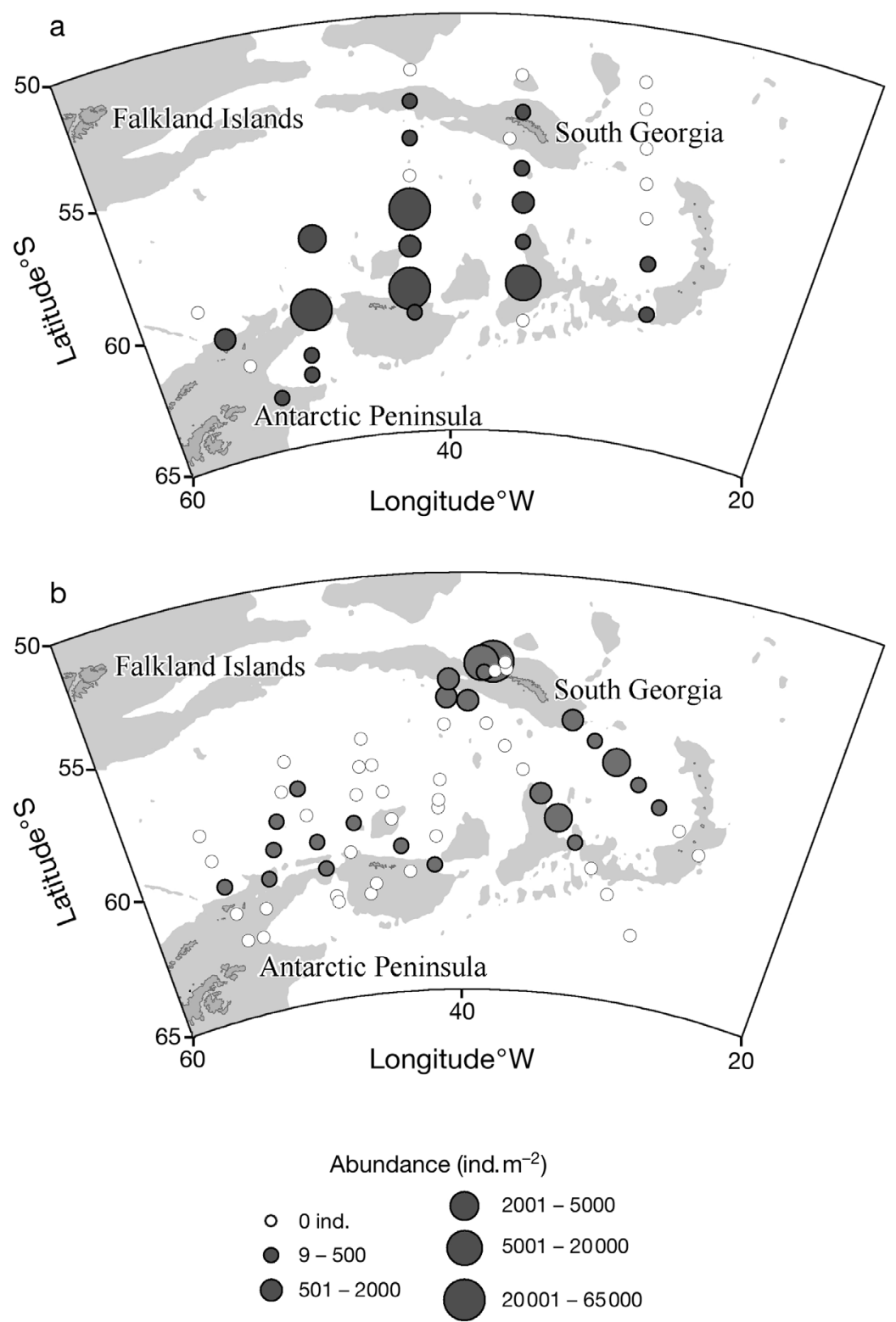

Fig. 9. Relative abundance and distribution of Euphausia superba larvae sampled during January and February (a) 2000 and (b) 2003. Abundance standardised to (a) ind. $\mathrm{m}^{-2}(0-200 \mathrm{~m})$ and (b) ind. $\mathrm{m}^{-2}(0-400 \mathrm{~m})$, except stations to north of South Georgia where data represent ind. $\mathrm{m}^{-2}(0-200 \mathrm{~m})$ sent in increasingly significant numbers in the more northerly parts of the survey region, reflecting the Bongo net analyses. An exception to these trends was apparent at the next to most southerly station on transect 7 , which had a population of $C$. acutus that, although low in abundance and largely comprised of later stages, was present in near surface waters, and also at stations to the north of South Georgia where $\mathrm{CV}$ C. acutus extended down to, and presumably in excess of, $1000 \mathrm{~m}$, undergoing autumnal descent.

\section{Sea-ice cover}

Ice-edge positions during cruise JR82 (January and February) in relation to the mean monthly position determined over the period 1979 to 2004 are presented in Fig. 7 along with comparable data for the CCAMLR 2000 cruise undertaken in January/February 2000 (see 'Discussion').

During the 2 mo of maximum seasonal sea-ice extent (August and September) approx. half of the station positions lying within the main body of the Scotia Sea are generally icecovered. By December the whole survey area, except a few stations in the southeastern sector, are normally clear of ice, and the whole area by January (Gloersen et al. 1992). During periods of maximum extent, ice-affected stations belonged mainly to zooplankton Stn Groups 2 and 4 with remaining station groups either unaffected (Stn Group 1) or only marginally so (Stn Group 3). From September 2002 onwards the ice edge retreated at rates broadly in line with the monthly mean positions (1979 to 2004) until November, when the retreat slowed, and continued to do so throughout the remaining summer months into 2003. Thus by December the ice edge lay many kilometres north of its mean December position, with the gap widening throughout January and into February 2003, during which month the area eventually became ice-free. During CCAMLR 2000, the ice edge retreated slightly faster than the seasonal mean, and the same area was free of ice at least 1 mo earlier. 


\section{DISCUSSION}

\section{Zooplankton community structure}

In line with previous studies in this and other sectors of the Southern Ocean, the various zooplankton groups identified here should be viewed as representing a single zooplankton community, albeit one with distinct regional differences in its phenological development (Marin 1987, Siegel et al. 1992, Pakhomov et al. 2000, Ward et al. 2004). Most species were present across the entire survey area, and changes in abundance were greater than those in species composition. Latitude emerged as the strongest single correlate with community pattern in the BIO-ENV analysis applied to the mesozooplankton data (Table 7). This is consistent with the latitudinal gradient in production cycles that exists within the Southern Ocean, with community development tending to commence earlier in the northern part of the ACC during spring and summer (Hart 1942, Voronina 1970). Previous surveys carried out in the Southern Ocean highlighted the importance of pack ice and temperature in influencing the distribution and composition of zooplankton communities (Mackintosh 1934, Marin 1987, Hosie et al. 2000, Ward et al. 2004). Hosie et al. (2000) found that temperature accounted for $\sim 50 \%$ of the variability in community patterns during a survey carried out in East Antarctica, whereas chl a accounted for $\sim 21 \%$ and was also slightly negatively correlated with total zooplankton abundance. They concluded that chl a per se was therefore relatively unimportant in the large-scale separation of zooplankton communities. The temperature association was however strongly related to latitude and did not explain east-west differences also apparent during their survey. Surface chl a was also a weaker correlate of overall community pattern in this study $(\rho=0.344)$. However, various food-related indices such as phytoplankton size, TFA and POC amounts and water column nutrient properties (a proxy for past production levels) figured prominently in explaining carbon mass and total abundance in the stepwise regression analysis (Table 9). Thus we have an apparent paradox in that, whilst C mass of some species and overall zooplankton abundance relate positively and strongly to measures of food biomass and quality, community pattern relates more strongly to latitude. Whilst most species are present across the entire survey area, regional differences, exemplified by the station groups, are not wholly attributable to differences in the timing of production across a uniform community. Many species, for example, have inherently differing distributions across the ACC, which reflect species ranges, different relationships with temperature (e.g. Mackintosh 1934) and different behaviours, all of which will tend to promote regional differences in community structure (Hosie et al. 2000). On the other hand species stages attributes such as $\mathrm{C}$ mass will tend to reflect the influence of proximate factors, e.g. available food, irrespective of patterns of distribution.

Table 7. Results of BIO-ENV analysis. Combinations of $K$ variables giving largest Spearman rank correlations $(\rho w)$ between mesozooplankton and environmental similarity matrices. First 3 models listed, best overall fit in bold. Environmental variables included were latitude, sea-surface temperature, chl a biomass $\left(\mathrm{mg} \mathrm{m}^{-2}, 0-100 \mathrm{~m}\right)$, nitrate $\left(\mathrm{NO}_{3}\right.$ average $\left.0-50 \mathrm{~m}, \mathrm{mmol} \mathrm{m}^{-3}\right)$, phosphate $\left(\mathrm{PO}_{4}\right.$ average $0-50 \mathrm{~m}$, $\mathrm{mmol} \mathrm{m}{ }^{-3}$ )

\begin{tabular}{|lcl|}
\hline$K$ & $\rho W$ & Environmental variables \\
\hline 1 & 0.608 & Lat \\
2 & $\mathbf{0 . 6 4 2}$ & Lat $+\mathbf{P O}_{4}$ \\
3 & 0.599 & Lat $+\mathrm{PO}_{4}+\mathrm{Chl} a$ \\
\hline
\end{tabular}

Table 8. Median C mass ( $\mu \mathrm{g})$ of Calanoides acutus copepodite stages CIV, CV and females, Rhincalanus gigas females and median $C$. acutus and $R$. gigas egg production rates (EPR) with respect to mesozooplankton station groups (lower and upper quartile ranges). $\mathrm{n}=$ no. of stations within station groups for which data are available out of possible total (second row)

\begin{tabular}{|c|c|c|c|c|}
\hline & $\begin{array}{l}\text { Group } 1 \\
(\mathrm{n}=10)\end{array}$ & $\begin{array}{l}\text { Group } 2 \\
(\mathrm{n}=21)\end{array}$ & $\begin{array}{l}\text { Group } 3 \\
(\mathrm{n}=10)\end{array}$ & $\begin{array}{l}\text { Group } 4 \\
(\mathrm{n}=19)\end{array}$ \\
\hline C. acutus CIV & $\begin{array}{c}46 \\
(37-64) \\
(\mathrm{n}=9)\end{array}$ & $\begin{array}{c}21 \\
(20-21) \\
(\mathrm{n}=3)\end{array}$ & $\begin{array}{c}24 \\
(20-30) \\
(\mathrm{n}=8)\end{array}$ & $\begin{array}{c}3 \\
(26-36) \\
(\mathrm{n}=9)\end{array}$ \\
\hline C. acutus CV & $\begin{array}{c}238 \\
(174-360) \\
(\mathrm{n}=8)\end{array}$ & $\begin{array}{c}59 \\
(29-80) \\
(\mathrm{n}=14)\end{array}$ & $\begin{array}{c}48 \\
(44-53) \\
(\mathrm{n}=8)\end{array}$ & $\begin{array}{c}129 \\
(41-187) \\
(\mathrm{n}=15)\end{array}$ \\
\hline C. acutus females & $(\mathrm{n}=0)$ & $\begin{array}{c}75 \\
(44-174) \\
(\mathrm{n}=16)\end{array}$ & $\begin{array}{c}65 \\
(62-78) \\
(\mathrm{n}=7)\end{array}$ & $\begin{array}{c}311 \\
(110-421) \\
(\mathrm{n}=12)\end{array}$ \\
\hline R. gigas females & $\begin{array}{c}1601 \\
(1086-2085) \\
(\mathrm{n}=7)\end{array}$ & $\begin{array}{c}455 \\
(-) \\
(\mathrm{n}=1)\end{array}$ & $\begin{array}{c}279 \\
(233-337) \\
(\mathrm{n}=9)\end{array}$ & $\begin{array}{c}570 \\
(349-804) \\
(\mathrm{n}=14\end{array}$ \\
\hline \multicolumn{5}{|l|}{ EPR } \\
\hline $\begin{array}{l}\text { C. acutus } \\
\left(\text { eggs female }{ }^{-1} \mathrm{~d}^{-1}\right)\end{array}$ & - & $\begin{array}{c}0 \\
(0-0) \\
(\mathrm{n}=17)\end{array}$ & $\begin{array}{c}3.3 \\
(0-10) \\
(\mathrm{n}=7)\end{array}$ & $\begin{array}{c}12 \\
(7-35) \\
(\mathrm{n}=13)\end{array}$ \\
\hline $\begin{array}{l}\text { R. gigas } \\
\left(\text { eggs female }{ }^{-1} \mathrm{~d}^{-1}\right)\end{array}$ & $\begin{array}{c}7.60 \\
3.7 \\
(2.3-14) \\
(\mathrm{n}=10)\end{array}$ & $\begin{array}{c}0 \\
(0) \\
(\mathrm{n}=2)\end{array}$ & $\begin{array}{c}1.4 \\
(0-4) \\
(\mathrm{n}=8)\end{array}$ & $\begin{array}{c}(0-7) \\
(n=16)\end{array}$ \\
\hline
\end{tabular}


Table 9. Selected models from best subsets regression analysis. Response variables tested against various predictor variables. Predictor variables included were latitude (Lat), sea-surface temperature $\left({ }^{\circ} \mathrm{C}\right), \%$ Chlor $>12 \mu \mathrm{m},(20 \mathrm{~m}) \% \mathrm{Chlor} 2-12 \mu \mathrm{m}(20 \mathrm{~m})$, surface chl a $\left(\mathrm{Chl} a, \mathrm{mg} \mathrm{m}^{-3}\right)$, POC $\left(\mu \mathrm{g} \mathrm{l} \mathrm{l}^{-1}, 20 \mathrm{~m}\right)$, nitrate $\left(\mathrm{NO}_{3}\right.$ average $\left.0-50 \mathrm{~m}, \mathrm{mmol} \mathrm{m}^{-3}\right)$, phosphate $\left(\mathrm{PO}_{4}\right.$ average $0-50 \mathrm{~m}$,

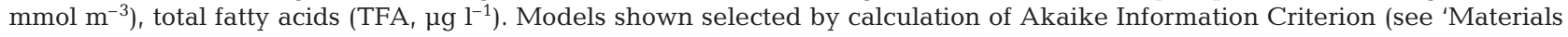
and methods' for explanation). Regression equations include (SE coefficient)

\begin{tabular}{|c|c|c|}
\hline Regression equations & $R^{2}(\%)$ & $\mathrm{p}$ \\
\hline Log C mass CIV C. acutus $=1.72(0.009)-0.009(0.001) \%$ Chl 2-12 $\mu \mathrm{m}$ & 47.9 & $<0.001$ \\
\hline Log C mass CV C. acutus $=-1.99(1.08)+0.636(0.081)$ Log Chl $a+0.072(0.019)$ Lat & 68.8 & $<0.001$ \\
\hline Log C mass female $R$. gigas $=2.62(0.40)+0.452(0.129)$ Log TFA $-0.028(0.008) \mathrm{NO}_{3}$ & 76.3 & $<0.001$ \\
\hline $\begin{array}{l}\sqrt{ } \text { Mesozooplankton Abundance }=40.3(7.3)+0.018(0.009) \% \mathrm{Chl}>12 \mu \mathrm{m}+3.22(1.11) \\
\text { Log POC }-1.77(0.69) \mathrm{PO}_{4}-0.052(0.101) \text { Lat } 79.7,<0.001 \mathrm{C} . \text { acutus } \mathrm{EPR}=-197(59.0)+ \\
0.311(0.059) \% \mathrm{Chl}>12 \mu \mathrm{m}+13.5(5.7) \text { Log TFA }+1.88(0.64) \mathrm{NO}_{3}+2.03(0.836) \text { Lat }\end{array}$ & 55.6 & $<0.001$ \\
\hline$R$ gigas EPR $=-25.9(12.6)+13.3(5.4)$ Log POC & 17.1 & 0.018 \\
\hline $\begin{array}{l}\text { Test of autocorrelation in residuals from fitted model based on trend in variogram (see text): } \\
\text { Log C mass } C \text {. acutus CIV }\left(R^{2}=1.9 \%, \mathrm{p}=0.51\right) ; \text { Log C mass } C \text {. acutus CV }\left(R^{2}=4.4 \%, \mathrm{p}=0.14\right) ; \\
\text { Log C mass female R. gigas }\left(R^{2}=6.0 \%, \mathrm{p}=0.07\right) ; \sqrt{ } \text { Mesozooplankton Abund. }\left(R^{2}=0.7 \%, \mathrm{p}=0.34\right) \\
\text { C. acutus EPR }\left(R^{2}=0.1 \%, \mathrm{p}=0.83\right) ; R \text {. gigas EPR }\left(R^{2}=1.9 \%, \mathrm{p}=0.28\right)\end{array}$ & & \\
\hline
\end{tabular}

Table 10. Median population depth (m), population abundance (ind. $\mathrm{m}^{-2}$, 0-1000 m) and mean stage (see text) for Calanoides acutus and Rhincalanus gigas sampled by LHPR with respect to station. For details of mean stage calculation see 'Materials and methods'. Stations arranged in order of decreasing latitude (Fig. 1)

\begin{tabular}{|c|c|c|c|c|c|c|c|}
\hline \multirow[t]{2}{*}{ Stn } & \multirow{2}{*}{$\begin{array}{c}\text { Sampling } \\
\text { day } \\
\text { (from } \\
1 \text { Jan) }\end{array}$} & \multicolumn{3}{|c|}{ Calanoides acutus } & \multicolumn{3}{|c|}{ Rhincalanus gigas } \\
\hline & & $\begin{array}{l}\text { Pop. } \\
\text { depth }\end{array}$ & Abund. & Stage & $\begin{array}{l}\text { Pop. } \\
\text { depth }\end{array}$ & Abund. & Stage \\
\hline 7.10 & 35 & 85 & 1484 & 5.05 & 435 & 113 & 5.80 \\
\hline 5.5 & 23 & 328 & 766 & 5.42 & 317 & 176 & 5.37 \\
\hline 6.2 & 27 & 348 & 1068 & 5.39 & 320 & 71 & 5.51 \\
\hline 6.4 & 28 & 60 & 709 & 3.77 & 273 & 468 & 5.10 \\
\hline 7.5 & 32 & 271 & 1641 & 4.55 & 320 & 537 & 5.42 \\
\hline 6.6 & 29 & 96 & 1143 & 3.85 & 102 & 637 & 4.92 \\
\hline 6.7 & 30 & 5 & 7151 & 4.76 & 5 & 3026 & 4.58 \\
\hline $\mathrm{W} 2.2 \mathrm{~N}$ & 49 & 177 & 3662 & 4.65 & 38 & 2294 & 3.21 \\
\hline
\end{tabular}

Phytoplankton and zooplankton station ordinations were similar insofar as patterns of abundance and groupings of stations were, in the main, geographically consistent with one another (Figs. 4 \& 6). In both ordinations the extremes were represented by the northerly South Georgia group of stations where diatoms dominated, in particular Eucampia sp., and zooplankton abundance and 'condition' were high, and low cell counts and low zooplankton abundance and 'condition' were found within the station groupings in the southern and western parts of the Scotia Sea (Tables 1, 5 \& 8). Independent observations made around South Georgia further highlighted the positive relationships between copepod population recruitment processes (as assayed by abundance, C mass of species stages and egg production indices) and the proportion of large diatoms present in water samples taken at these stations (Shreeve et al. 2002, Ward et al. 2005) and in the diet of many of the species present (Atkinson 1994). These findings strongly suggest the importance of bottom-up factors on Southern Ocean mesozooplankton communities, and food limitation has been identified as a major control, particularly in ironlimited regions (Smetacek et al. 2004).

\section{Population development}

Given the extent to which the zooplankton station groupings identified in this study represent a single 'community' at different stages in its phenological development, it is possible to provide an estimate of the extent to which some of its elements are chronologically separated. Differences in species and community development have been reported across the 600 nautical mile $(1000 \mathrm{~km})$ extent of the Scotia Sea during summer, as production cycles tend to proceed earlier in the ice-free northern parts. For example, Ward et al. (2004) reported differences in stage composition equivalent to a 3 mo advance in population development of Calanoides acutus from the northern part of the Scotia Sea compared to that south of the Weddell Front. Marin (1987) also found pronounced latitudinal age differences for $C$. acutus and Calanus propinquus during the Melville study of 1981. 
Data from the LHPR profiles carried out on JR82 clearly exemplified such differences in terms of depth distribution, stage composition and abundance. In the southern part of the survey area within zooplankton Group 2, median population depths for C. acutus were $\sim 330$ to $350 \mathrm{~m}$ (Table 10). The low abundance, high proportion of females and deep median population depth at this time of year are indicative of an ongoing 'spring ascent' rather than a seasonal descent as might be expected in the more northern parts of the Scotia Sea (Atkinson et al. 1997).

Given that the stations were sampled at the end of January, it is remarkably late in the year for a population to be at the pre-recruitment stage in its development. It is presently unclear as to what cues cause plankton populations to ascend from overwintering depths back to surface waters or whether sea-ice cover is implicated in this process. Sea-ice cover can reduce primary production due to decreased light penetration, and therefore the ability of zooplankton populations to reproduce and develop at optimal rates in the surface layers; alternatively, a retreating ice edge may provide stabilisation of the water column and allow bloom conditions to develop. In an earlier study in the Bellingshausen Sea, Atkinson \& Shreeve (1995) described the spring differences in population processes and depth distribution, stage development and chlorophyll in the water column in relation to ice cover. The Calanoides acutus population lay considerably deeper in the water column under pack ice compared to the ice edge and open water. Likewise the population was overwintered under the ice and reproduction was only apparent at the ice edge and in open water where chl a levels were higher. A similar situation was reported by Burghart et al. (1999) in a study of the marginal ice zone in the Weddell Sea during spring.

At the northern end of transect 6 both Calanoides acutus and Rhincalanus gigas were present in near surface waters and undergoing recruitment, whereas to the north of South Georgia, in early February, C. acutus was undergoing its seasonal descent. Thus based on development times determined by Shreeve (2002), population development of C. acutus at its spatial extremes within the Scotia Sea varied temporally by at least 3 mo and possibly more (Fig. 8).

\section{Comparison of JR82 and CCAMLR 2000}

Both cruises took place during January and February during 2 summers that differed greatly in terms of the rate of ice retreat and the distribution of phytoplankton biomass. During CCAMLR 2000, a 4-ship survey, 123 plankton samples were collected with RMT1 nets ( 0 to $250 \mathrm{~m}$ ) across an area extending from $\sim 20$ to $70^{\circ} \mathrm{W}$. Subsequent analysis indicated the existence of 2 main groups of stations which essentially formed a northern 'warm' and a southern 'cold' water community (Ward et al. 2004). Because of taxonomic similarities it was concluded that the two communities represented a single community differing only in phenological development and the mass occurrence of patchily distributed organisms such as krill larvae. The area surveyed during the present cruise was not as extensive, nor the sample size as large, but the same basic trends were detected in the data. A set of Bongo net samples (0 to $200 \mathrm{~m}$ ) collected during CCAMLR $2000(\mathrm{n}=31$ ) also reflected this pattern and additionally served to confirm the delayed development of Calanoides acutus and to a lesser extent Rhincalanus gigas populations during JR82. During CCAMLR 2000 the new generation of $C$. acutus was present throughout the Scotia Sea, but during JR82 an overwintered generation dominated by pre-recruitment females and CVs was extensively found throughout the central and southern regions (Fig. 8).

Also of note was the differing distribution of krill larvae during the 2 cruises (Fig. 9). During CCAMLR 2000 early calyptopes were locally abundant throughout the southern central part of the Scotia Sea but were concentrated along both sides of the Weddell Front (Siegel et al. 2004). In this area spawning generally commences in late November or early December and has a variable but normally long duration of 3 to 3.5 mo (Spirodonov 1995). This variability in timing has also been documented by Brinton et al. (1986), and conditions for successful spawning in the Long-Term Ecosystem Research region of the Antarctic Peninsula have been positively linked to average sea-ice extent (Quetin \& Ross 2003). In contrast, in the Antarctic Marine Living Resources region, $450 \mathrm{~km}$ further north, where krill have recently been hypothesised to be at the edge of their reproductive range (Quetin \& Ross 2003), extensive sea ice (> average extent during summer) appears to enhance successful spawning (Siegel \& Loeb 1995). Although complex, both hypotheses make explicit links to available food and the balance of under-ice and open-ocean food concentrations. As a general rule, bloom conditions within the Scotia Sea are often transient, chlorophyll rarely exceeds $1.5 \mathrm{mg}$ $\mathrm{m}^{-3}$ (Trégeur \& Jacques 1992), and as a consequence zooplankton populations may suffer severe food limitation (see also Huntley \& Brinton 1991).

During JR82, krill larvae were abnormally distributed, being found in oceanic waters to the northwest of South Georgia, although T/S profiles indicated that the water here may have originated to the south of the SACCF. Chl a levels in the western part of the Scotia Sea were low during JR82, and the presence of unmated female krill with developing ovaries in the 
normal spawning areas alongside sub-adult males (Shreeve pers. comm.) suggests that any shortfalls in food for the energetically expensive process of sexual maturation were felt more by males. In contrast, during CCAMLR 2000 when krill larvae were abundant, relatively high chl a levels were widespread and associated with water column profiles where temperature and density indicated mixing of ACC waters with waters originating either from coastal regions or by upwelling of deeper waters associated with bathymetric features (Holm-Hansen et al. 2004, their Fig. 2).

The presence of abundant krill larvae and the new generation of Calanoides acutus across the southern part of the Scotia Sea during January 1981 has also been reported by Brinton (1985) and Marin (1987) respectively. During 1981 monthly ice-edge positions were close to the long-term average as the ice retreated across the Scotia Sea from an extreme northerly position in September 1980 to a minimum in February 1981. The rates of ice retreat during JR82 and CCAMLR 2000 were largely indistinguishable from the mean value until, in the case of JR82, December, when the retreat of the ice edge slowed. During January it moved very little, particularly in the eastern part of the survey region (Fig. 7). The slow retreat continued throughout February when the survey area finally became ice-free a month later than during CCAMLR 2000.

It was noticeable that during JR82, in addition to the bloom conditions seen to the north of South Georgia, SeaWiFS images also showed blooms to be patchily present along transects 7 and 8 (see Korb et al. 2005, their Fig. 5). Blooms may at times be associated with the retreating ice edge, particularly where the freshening effect imparts stratification and stability (Nelson et al. 1987, Lancelot et al. 1993). Density sections taken along both of these transects showed a far greater degree of upper water column stratification and hence stability than elsewhere (Korb et al. 2005). Low chlorophyll levels pervaded much of the rest of the Scotia Sea, particularly in the regions of zooplankton Groups 2 and 3. Taken together these observations suggest that the presence of sea ice can strongly influence secondary producers and the timing of production cycles in contrasting ways. The 2 years (1981 and 2000) in which ice retreat occurred broadly in line with the 25 yr mean were characterised by an abundance of krill larvae and the presence of a spring generation of copepods throughout the southern Scotia Sea. The later retreat experienced during 2003 was characterised by overwintered populations of copepods being present well into the summer months and a dearth of krill larvae in areas where spawning generally takes place. However, to the east the presence of a bloom that appeared to be initiated along the retreating ice edge was coincident with higher EPRs of Calanoides acutus and a shallower median population depth than at comparable latitudes further west.

\section{CONCLUSIONS}

The relationships disclosed in this and other studies between attributes of chl a (size, amount, quality, etc.) and zooplankton abundance and $\mathrm{C}$ mass supports the idea that for much of the time Southern Ocean zooplankton are food limited and are sensitive to changes in production (Ross et al. 2000, Shreeve et al. 2002, Quetin \& Ross 2003, Ward et al. 2005, this study). Marine communities in the North Atlantic appear to be regulated by climatic phenomena that exert their influence either through temperature-mediated responses or through changes in wind fields and oceanic circulation (Fromentin \& Planque 1996, Planque \& Taylor 1998). The coupling of atmospheric and oceanic processes in the Southern Ocean is not yet well enough understood to enable predictions as to how future climate change may influence production patterns. The likelihood is that change will be complex as reflected in recent work by Edwards \& Richardson (2004), who have shown that in the temperate North Atlantic the marine pelagic community is responding to climate change, although the level of response differs within communities and between different trophic groups, which is leading to mismatches between successive trophic levels. Quantifying the impacts sea-ice dynamics have on production cycles will be an important part of understanding community structure and function in the Southern Ocean.

Acknowledgements. We thank the officers and crew on board RRS 'James Clark Ross' for their great help in the successful completion of this cruise. Our many colleagues who participated in the collection of various datasets throughout the cruise are also gratefully acknowledged. We are grateful to A. Fleming for accessing all satellite data, provided courtesy of NASA GSFC (Goddard Distributed Active Archive Center) and NOAA. B. Clarke (Plymouth) and P. Rothery (Monks Wood) are thanked for their discussion and advice regarding appropriate statistical procedures. We thank the referees for their careful reading of the manuscript that did much to improve it.

\section{LITERATURE CITED}

Andrews KJH (1966) The distribution and life-history of Calanoides acutus (Giesbrecht). Discov Rep 24:117-162

Atkinson A (1991) Life cycles of Calanoides acutus, Calanus simillimus and Rhincalanus gigas (Copepoda: Calanoida) within the Scotia Sea. Mar Biol 109:79-91

Atkinson A (1994) Diets and feeding selectivity among the epipelagic copepod community near South Georgia in summer. Polar Biol 14:551-560 
Atkinson A, Shreeve RS (1995) Response of the copepod community to a spring bloom in the Bellingshausen Sea. Deep-Sea Res II 42:1291-1311

Atkinson A, Schiel SB, Ward P, Marin V (1997) Regional differences in the life cycle of Calanoides acutus (Copepoda: Calanoida) within the Atlantic sector of the Southern Ocean. Mar Ecol Prog Ser 150:99-111

Atkinson A, Siegel V, Pakhomov EA, Rothery P (2004) Longterm decline in krill stock and increase in salps within the Southern Ocean. Nature 432:100-103

Boysen-Ennen E, Hagen W, Hubold G, Piatkowski U (1991) Zooplankton biomass in the ice covered Weddell Sea. Mar Biol 111:227-235

Brinton E (1985) The oceanographic structure of the eastern Scotia Sea. III. Distributions of euphausiid species and their developmental stages in 1981 in relation to hydrography. Deep-Sea Res I 32:1153-1180

Brinton E, Huntley M, Townsend AW (1986) Larvae of Euphausia superba in the Scotia Sea and Bransfield Strait in March 1984 - development and abundance compared with 1981 larvae. Polar Biol 5:221-234

Brinton E, Loeb VJ, Macauley MC, Schulenberger E (1987) Variability of Euphausia superba populations near Elephant Island and the South Shetlands: 1981 vs. 1984. Polar Biol 7:345-362

Burghart SE, Hopkins TL, Vargo GA, Torres JJ (1999) Effects of a rapidly receding ice edge on the abundance, age structure and feeding of three dominant calanoid copepods in the Weddell Sea, Antarctica. Polar Biol 22:279-288

Burnham KP, Anderson DR (2002) Model selection and multimodel inference. A practical information-theoretic approach, 2nd edn. Springer, New York

Christie WW (1982) Lipid analyses, 2nd edn. Pergamon, Oxford, p 52-53

Clarke KR, Ainsworth M (1993) A method of linking multivariate community structure to environmental variables. Mar Ecol Prog Ser 92:205-219

Clarke KR, Warwick RM (2001) Changes in marine communities: an approach to statistical analysis and interpretation, 2nd edn. PRIMER-E, Plymouth, p 1-172

Cressie NAC (1993) Statistics for spatial data, 2nd edn. Wiley, New York

Edwards M, Richardson AJ (2004) Impact of climate change on marine pelagic phenology and trophic mismatch. Nature 430:881-883

Edwards M, Beaugrand G, Reid PC, Rowden M, Jones A (2002) Ocean climate anomalies and the ecology of the North Sea. Mar Ecol Prog Ser 239:1-10

Errhif A, Razouls C, Mayzaud P (1997) Composition and community structure of the pelagic copepods in the Indian sector of the Antarctic Ocean during the end of the austral summer. Polar Biol 17:418-430

Field JG, Clarke KR, Warwick RM (1982) A practical strategy for analysing multispecies distribution patterns. Mar Ecol Prog Ser 8:37-52

Folch J, Lees N, Sloane-Stanley GH (1957) A simple method for the isolation and purification of total lipid. J Biol Chem 226:497-509

Franks PJS (1992) Sink or swim: accumulation of biomass at fronts. Mar Ecol Prog Ser 82:1-12

Fransz HG, Gonzalez SR (1997) Latitudinal metazoan plankton zones in the Antarctic Circumpolar Current along $6^{\circ} \mathrm{W}$ during austral spring 1992. Deep-Sea Res II 44:395-414

Fromentin JM, Planque B (1996) Calanus and environment in the eastern North Atlantic. II. Influence of the North Atlantic Oscillation on C. finmarchicus and C. helgolandicus. Mar Ecol Prog Ser 134:111-118
Gloersen P, Campbell WJ, Cavalieri DJ, Comiso JC, Parkinson CL, Zwally HJ (1992) Arctic and Antarctic sea ice, 1978-1987: satellite passive-microwave observations and analysis (NASA; SP-511). National Aeronautics and Space Administration Washington, DC

Hart T (1942) Phytoplankton periodicity in Antarctic surface waters. Discov Rep 21:261-356

Holm-Hansen O, Naganobu M, Kawaguchi S, Kameda T and 9 others (2004) Factors influencing the distribution, biomass and productivity of phytoplankton in the Scotia Sea and adjoining waters. Deep-Sea Res II 51:1333-1350

Hosie GW (1994) The macrozooplankton communities in the Prydz Bay region, Antarctica. In: El Sayed SZ (ed) Southern ocean ecology: the BIOMASS perspective. Cambridge University Press, Cambridge, p 93-123

Hosie GW, Schultz MB, Kitchener JA, Cochran TG, Richards K (2000) Macrozooplankton community structure off East Antarctica $\left(80-150^{\circ} \mathrm{E}\right)$ during the austral summer of 1995/1996. Deep-Sea Res II 47:2437-2463

Huntley M, Brinton E (1991) Mesoscale variation in growth and early development of Euphausia superba Dana in the western Bransfield Strait region. Deep-Sea Res II 38:1213-1240

Korb R, Whitehouse M (2004) Contrasting primary production regimes around South Georgia, Southern Ocean: mega blooms vs high nutrient low chlorophyll waters. Deep-Sea Res I 51:721-738

Korb RE, Whitehouse MJ, Thorpe SE, Gordon M (2005) Primary production across the Scotia Sea in relation to the physico-chemical environment. J Mar Syst 57:231-249

Lancelot C, Mathot S, Veth C, de Baar HJW (1993) Factors controlling phytoplankton ice-edge blooms in the marginal ice-zone of the northwestern Weddell Sea during sea-ice retreat 1998 - field observations and mathematical modelling. Polar Biol 13:377-387

Longhurst A (1998) Ecological geography of the sea. Academic, London

Mackintosh NA (1934) Distribution of macroplankton in the Atlantic sector of the Antarctic. Discov Rep 9:65-160

Marin V (1987) The oceanographic structure of the Scotia Sea-IV. Distribution of copepod species in relation to hydrography in 1981. Deep-Sea Res I 34:105-121

Marr JWS (1962) The natural history and geography of the Antarctic krill (Euphausia superba Dana). Discov Rep 32:33-464

Nelson DM, Smith WO, Gordon LI, Huber BA (1987) Spring distributions of density, nutrients, and phytoplankton biomass in the ice edge zone of the Weddell-Scotia Sea. J Geophys Res Oceans 92(C7):7181-7190

Pakhomov EA, Perissinotto R, McQuaid CR, Froneman PW (2000) Zooplankton structure and grazing in the Atlantic sector of the Southern Ocean in late austral summer 1993. Part 1. Ecological zonation. Deep-Sea Res I 47:1663-1686

Piatkowski U (1989) Macroplankton communities in Antarctic surface waters: spatial changes related to hydrography. Mar Ecol Prog Ser 55:251-259

Planque B, Taylor AH (1998) Long-term changes in zooplankton and the climate of the North Atlantic. ICES J Mar Sci 55:644-654

Quetin LB, Ross RM (2003) Episodic recruitment in Antarctic krill Euphausia superba in the Palmer LTER study region. Mar Ecol Prog Ser 259:185-200

Ross RM, Quetin LB, Baker KS, Vernet M, Smith RC (2000) Growth limitation in young Euphausia superba under field conditions. Limnol Oceanogr 45:31-43

Scott FJ, Marchant HJ (2005) Antarctic marine protists. Canberra: Australian Biological Resources Study, Hobart: Australian Antarctic Division 
Shreeve RS (2002) Growth of two species of Southern Ocean copepod in relation to their environment. PhD thesis, Open University, Milton Keynes, UK

Shreeve RS, Ward P, Whitehouse MJ (2002) Copepod growth and development around South Georgia: relationships with temperature, food and krill. Mar Ecol Prog Ser 233: 169-183

Siegel V, Loeb V (1995) Recruitment of Antarctic krill (Euphausia superba) and possible causes for its variability. Mar Ecol Prog Ser 123:45-56

Siegel V, Skibowski A, Harm U (1992) Community structure of the epipelagic zooplankton community under the seaice of the northern Weddell Sea. Polar Biol 12:15-24

Siegel V, Kawaguchi S, Ward P, Litvinov FF, Sushin VA, Loeb VJ, Watkins JL (2004) Krill demography and large-scale distribution in the southwest Atlantic during January/ February 2000 Deep-Sea Res II 51:1253-1273

Sievers HA, Nowlin WD (1984) The stratification and water masses at Drake Passage. J Geophys Res 89(C6): 10489-10514

Smetacek V, Assmy P, Henjes J (2004) The role of grazing in structuring Southern Ocean pelagic ecosystems and biogeochemical cycles. Antarct Sci 16:541-558

Spirodonov VA (1995) Spatial and temporal variability in reproductive timing of Antarctic krill (Euphausia superba Dana) Polar Biol 15:161-174

Tréguer P, Jacques G (1992) Dynamics of nutrients and phytoplankton, and fluxes of carbon, nitrogen and silicon

Editorial responsibility: Otto Kinne (Editor-in-Chief), Oldendorf/Luhe, Germany in the Antarctic Ocean. Polar Biol 12:149-162

Utermöhl H (1958) Zur Vervollkommnung der quantitativen Phytoplankton-methodik. Mitt Int Ver für Theor Angew Limnol 9:38

Voronina NM (1970) Seasonal cycles of some common copepod species. In: Holdgate M (ed) Antarctic ecology, Vol 1. Academic, London, p 162-172

Ward P, Shreeve RS (1995) Egg production in three species of Antarctic Calanoid copepods during an austral summer. Deep-Sea Res I 42:721-735

Ward P, Whitehouse M, Meredith MP, Murphy EJ and 9 others (2002) The Southern Antarctic Circumpolar current: physical and biological coupling at South Georgia. Deep-Sea Res I 49:2183-2202

Ward P, Grant S, Brandon M, Siegel V, Sushin V, Loeb V, Griffiths $H$ (2004) Mesozooplankton community structure in the Scotia Sea during the CCAMLR 2000 survey: JanuaryFebruary 2000. Deep-Sea Res II 51:1351-1367

Ward P, Shreeve R, Whitehouse M, Korb B and 6 others (2005) Phyto- and zooplankton community structure and production around South Georgia (Southern Ocean) during summer 2001/02. Deep-Sea Res I 52:421-441

Whitehouse MJ (1997) Automated seawater nutrient chemistry. British Antarctic Survey, Cambridge, p 1-16

Whitehouse MJ, Priddle J, Symon C (1996) Seasonal and annual change in seawater temperature, salinity, nutrient and chlorophyll a distributions around South Georgia, South Atlantic. Deep-Sea Res I 43:425-443

Submitted: December 20, 2004; Accepted: September 1, 2005 Proofs received from author(s): January 27, 2006 